\title{
Synthesis, applications and Structure-Activity Relationship (SAR) of cinnamic acid
}

\section{derivatives: a review}

Síntese, aplicações e Relação Estrutura-Atividade (REA) de derivados de ácido cinâmico: uma revisão

Síntesis, aplicaciones y Relación Estructura-Actividad (REA) de los derivados del ácido cinámico: una revisión

\begin{abstract}
The article aims to analyze the progress of the evolution of cinnamic acid derivatives through a bibliographic review, describing the main synthetic routes in obtaining this class, as well as remarkable biological applications and application of the structure-activity relationship (SAR) as a strategy for design pharmacologically active molecules. The methodology used consists of reading and analyzing articles, whose approach is descriptive, with data being collected regarding the therapeutic potential of derivatives of cinnamic acid and its relationship with structural scaffolding, as well as the most widely used synthetic approaches. As a result, it was observed that cinnamic acid and its derivatives from natural sources can be synthesized in appreciable quantities with varied synthetic routes, as well as being candidates for therapeutic agents, since they have several therapeutic applications against diabetes, infectious and degenerative diseases, among others, in addition to presenting activity such as pest control, which has attracted the attention of academic and industrial researchers. These compounds are highly versatile since their activity is intrinsically associated with the mode of interaction between the structure and its molecular target. However, in nature they are obtained in small quantities, therefore, the development of new approaches of synthetic methodologies to obtain such compounds in substantial quantities and linked to medicinal chemistry can contribute to the development of very effective bioactive molecules in comparison with their precursors.
\end{abstract}

Keywords: Phytochemicals; Pharmacological; Pharmaceutical., Chemistry; Chemical synthesis techniques; Biosynthesis.

\section{Resumo}

O artigo tem por objetivo analisar o progresso da evolução dos derivados do ácido cinâmico por meio de uma revisão bibliográfica, descrevendo as principais rotas sintéticas na obtenção dessa classe, bem como as notáveis aplicações biológicas e aplicação da relação estrutura-atividade (SAR) como estratégia para projetar moléculas farmacologicamente ativas. A metodologia empregada consistiu na leitura e análise de artigos, cuja abordagem foi descritiva, sendo feito o levantamento de dados no que tange as potencialidades terapêuticas dos derivados do ácido 
cinâmico e sua relação estrutural, assim como as abordagens sintéticas mais utilizadas. Como resultado observou-se que o ácido cinâmico e seus derivados oriundos de fontes naturais podem ser sintetizados em quantidades apreciáveis por rotas sintéticas variadas, e que são bons candidatos a agentes terapêuticos, já que apresentam diversas aplicações terapêuticas contra diabetes, doenças infecciosas, degenerativas entre outras. Além disso, apresentam atividades como controle de pragas, o que vem chamando a atenção de pesquisadores do meio acadêmico e industrial. Esses compostos são altamente versáteis visto que sua atividade está intrinsecamente associada ao modo de interação entre a estrutura e seu alvo molecular. Contudo, na natureza são obtidos em pequenas quantidades, portanto, o desenvolvimento de novas abordagens de metodologias sintéticas visando obter tais compostos em quantidades substanciais e ligadas à química medicinal podem contribuir para o desenvolvimento de moléculas bioativas eficazes em comparação aos seus precursores.

Palavras-chave: Compostos fitoquímicos; Farmacológica; Química farmacêutica; Técnicas de síntese química; Biossíntese.

\section{Resumen}

El artículo tiene como objetivo analizar el avance de la evolución de los derivados del ácido cinámico a través de una revisión bibliográfica, describiendo las principales vías sintéticas en la obtención de esta clase, así como las aplicaciones biológicas destacables y la aplicación de la relación estructura-actividad (SAR) como estrategia para diseñar moléculas farmacológicamente activas. La metodología empleada consiste en la lectura y análisis de artículos, cuyo abordaje es descriptivo, recogiéndose datos sobre el potencial terapéutico de los derivados del ácido cinámico y su relación con el andamiaje estructural, así como los abordajes sintéticos más utilizados. Como resultado, se observó que el ácido cinámico y sus derivados de fuentes naturales pueden sintetizarse en cantidades apreciables con variadas rutas sintéticas, además de ser candidatos a agentes terapéuticos, ya que tienen varias aplicaciones terapéuticas contra la diabetes, enfermedades infecciosas y degenerativas, entre otros, además de presentar actividades como el control de plagas, que ha llamado la atención de investigadores académicos e industriales. Estos compuestos son muy versátiles ya que su actividad está intrínsecamente asociada con el modo de interacción entre la estructura y su objetivo molecular. Sin embargo, en la naturaleza se obtienen en pequeñas cantidades, por lo que el desarrollo de nuevos enfoques de metodologías sintéticas para obtener dichos compuestos en cantidades sustanciales y vinculados a la química médica puede contribuir al desarrollo de moléculas bioactivas muy efectivas en comparación con sus precursores.

Palabras clave: Compuestos fitoquímicos; Farmacología; Química farmacêutica; Técnicas de síntesis química; Biosíntesis.

\section{Introduction}

Phytochemical compounds come from natural sources and play a vital role in their development, in addition to being governed by the therapeutic potential that can benefit human health. Among the numerous classes, cinnamic acid and its derivatives from the biosynthetic pathway of shikimic acid stand out (Vogt, 2010). Since the dawn of civilisation, they have been utilised in folk medicine considering their multiple therapeutic actions, such as antiseptics, insecticides, stimulants, and carminatives (De et al., 2011; Guzman, 2014).

Considering the interaction between structure and molecular target, cinnamic acid and its derivatives have been constantly reported to present several biological activities. However, the concentrations found in plant sources are low, and their use on a large scale is not feasible. On the other hand, with organic synthesis, it is possible to obtain considerable amounts of molecules from simple to complex structures and contribute to the industrial market. Based on this, studies on medicinal chemistry applying organic synthesis and computational methods might largely contribute to the development of new drugs or insecticides. In addition, those compounds present simple structures, which enables large-scale production (Pawar et al., 2011; Augustine et al., 2014).

Therefore, this work aims to show by means of bibliographic clippings that cinnamic acid and its derivatives are good candidates for therapeutic agents, since they have several therapeutic potentialities that are related to their structure, which is simple and versatile, corroborating in several studies of structure-activity relationship, and thus correlate medicinal and pharmaceutical chemistry with organic synthesis, showing the main synthetic routes that can be used in the production of this class of compounds. 


\section{Methodology}

This article consisted of a bibliographic review with a qualitative approach following the criteria established by Pereira A.S. et al. (2018); Kooti W. et al. (2017) e Untura L.P \& Rezende L.F. (2012), respectively. The data survey was carried out in a criterion way, selecting the most relevant articles in the last 10 years, associated with the cinnamic acid derivatives and their current application, considering their biological activities related to the structure-activity. Medical chemistry, on its turn, was applied using the structure-activity relationship (SAR) approach in a multidisciplinary way, as well as the organic synthesis, being shown the most usual synthetic strategies in the formation of this class of compounds, with a critical eye.

For data extraction, the following platforms were used: Capes Periodicals, PubMed, ScieLO, and Science Direct, from which 64 articles were selected, using the following descriptors: derived from cinnamic acid, biological activity, synthetic route, structure-activity relationship, and biosynthesis. The data collected were critically discussed, applying the related areas' multidisciplinarity to valorize the cinnamic acid and its derivatives since they have versatile and straightforward structures with promising therapeutic potential that should be explored and thus contribute to the development of science and technology.

\section{Results and Discussion}

\subsection{Bioactivity of cinnamic acid and its derivatives}

In the last 10 years, the attention of both scientific community and pharmaceutical industry on the cinnamic acid (CA) (1) and derivatives (2-5) (Figure 1) has particularly increased, once they have showed several potential therapeutic activities, such as anti-inflammatory, antioxidant, antiviral, antibacterial, and antifungal. Likewise, multiple anticancer activities by inhibiting the growth of mammary (MCF-7) and prostatic (PC-3) neoplastic cells by inducing apoptosis (Gunia-Krzyżak et al., 2018; Pontiki et al., 2014; Jitareanu et al., 2013; Martínez-Soriano et al., 2015; Imai et al., 2019).

Figure 1. Cinnamic acid and its derivatives naturally observed.

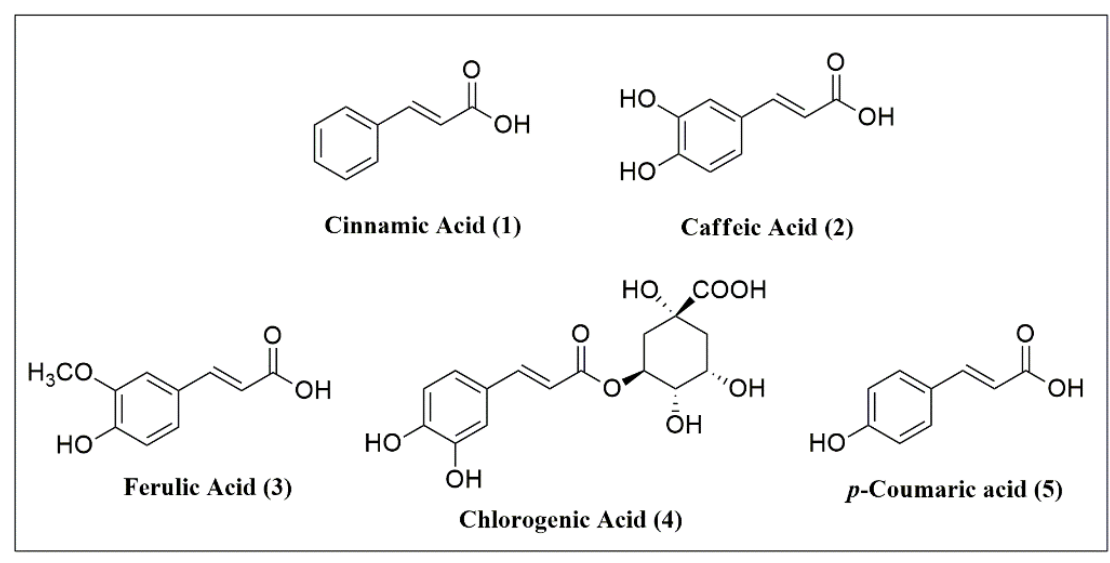

Fonte: Jitareanu et al., (2013); Gunia-Krzyżak et al., (2018).

The cinnamic acid (CA) (1) (Figure 1) is a natural product which displays low toxicity to several living organisms. It is found in vegetal species, especially Cinnamomum zeylanicum, which gave rise to the term "cinnamic." That simple structure is also involved in crucial functions such as growth, development, reproduction, and the defence system of various plant species. Those properties are similarly displayed by its derivatives, such as caffeic (2), ferulic (3), chlorogenic (4), and $p$ coumaric (5) acids (Figure 1), which might also be obtained from vegetal sources (De et al., 2011; Zeng \& Lai, 2019). 
Furthermore, there are currently observations on the biological activity of cinnamic acid derivatives (CAD), for instance, $p$-coumaric acid (5) and p-ethoxycinnamic acid (6) (Table 1) in the treatment of skin pigmentation disorders acting on the regulation of the melanogenesis process via mixed enzymatic inhibition of tyrosinase (Cui et al., 2016; Gunia-Krzyżak et al., 2018). Also, other derivatives present in plant species such as A. australasium and Schinus terebinthifolius have shown antioxidant and larvicidal activities against Aedes aegypti (Zeng \& Lai, 2019; Procópio et al., 2015). Hence, it appears that several derivatives (7-24) from this chemical class can act in different biological systems (see Table 1).

Table 1. Biological activity and mechanism of action of cinnamic acid derivatives.

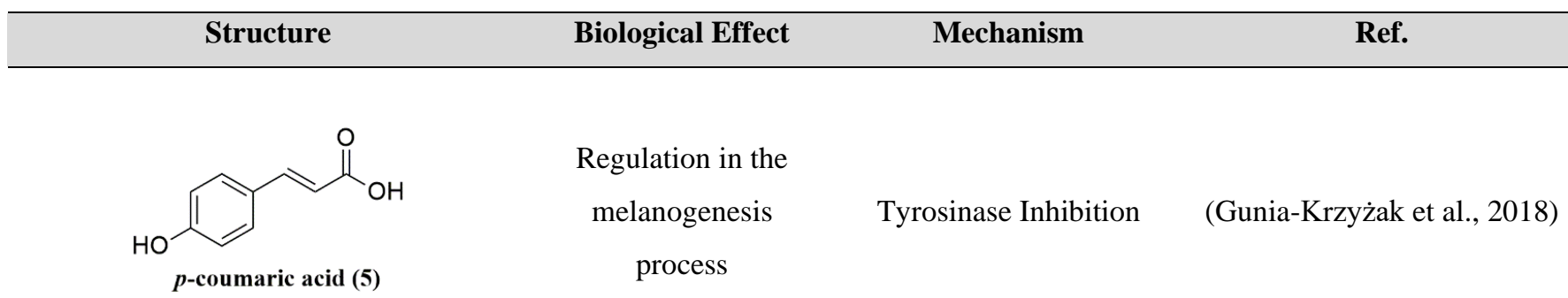

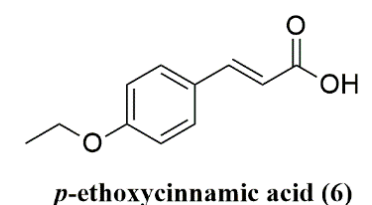

p-ethoxycinnamic acid (6)
Regulation in the

melanogenesis process
Tyrosinase Inhibition

(Cui et al., 2016)<smiles>O=C(O)/C=C/c1cccc(C(F)(F)F)c1</smiles>

m-trifluoromethylcinnamic acid (7)
Antifungal (Pleurotus ostreatus)

\section{CYP53A15 Enzyme}

Inhibition

(Sova et al., 2013)

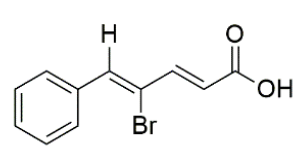

4-bromo-5-phenylpenta- 2,4dienoic acid (8)
Antioxidant

\section{Lipid peroxidation inhibition;}

lipoxygenase inhibition; and anticancer<smiles>COc1cc(/C=C/C(=O)O)ccc1O</smiles>

4-hydroxy-3-methylcinnamic acid (9)
Myoblast of the C2C12

cell line via protein

kinase and extracellular

(Kuppusamy et al., 2019)

signalling pathways. 
<smiles>COc1ccc(/C=C/C(=O)O)cc1O</smiles>

Isoferulic acid (10)
Protection against

apoptosis and

dysfunction of pancreatic cells; and

antioxidant
Enzymatic activity increasing of glyoxalase

(Meeprom et al., 2018)<smiles>COC1=CC2C=CC=NC2C(NC(C)CCCNC(=O)/C=C/c2ccccc2F)=C1</smiles>

(E)-3-(2-fluorophenyl)-N-(4-

((6-methoxy-4a,8a dihydroquinolin-8-yl)

amino)pentyl)acrylamide (11)

$\begin{array}{cc}\text { Anticancer } & \text { Cell growth inhibition by } \\ \text { (breast) } & \text { apoptosis induction }\end{array}$

(Mabeta et al., 2018)<smiles>CCCCCCOC(=O)/C=C/c1cc(O)c(O)c(O)c1</smiles>

Decayl 3,4,5-trihydroxycinnamate (12)<smiles>COc1cc(OC)c(OC)cc1/C=C/COC(=O)/C=C/c1c(OC)cc(OC)c(OC)c1OC</smiles>

(E) -3- (2,4,5-trimethoxyphenyl) ally- $(E)-3-$ (2,3,4,6-tetramethoxyphenyl) acrylate (13)
Anticancer (breast and prostatic)
Cell growth inhibition by apoptosis induction
(Imai et al., 2019)
Anticonvulsive Lactic dehydrogenase inhibition
(Bai et al., 2019)

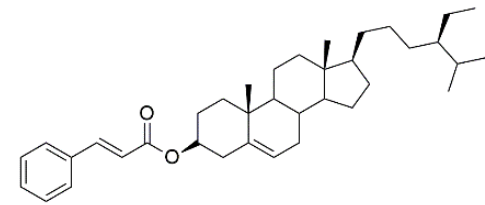

$(3 R, 10 R, 13 R, 17 S)$-17 - ((R) -4-ethyl-5-methylhexyl) -

10,13 -dimethyl $2,3,4,7,8,9,10,11,12,13,14,15,16,17$

tetradecahydro-1H-cyclopenta [a] phenantren-3-y] cinnamate (14)

\section{Tribolium castaneum}

Insecticide

(Brown beetle - Plague

of crop grains)
(Buxton et al., 2019) 


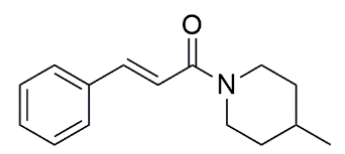

4-methoxy-piperidine cinnamoyl

(15)
Antifungal:

(Cochliobolus

lunatus, Aspergillus CYP53A15 Enzyme

niger and Pleurotus

ostreatus)

\section{Structure}

Biological Effect
Ref.

Staphylococcus aureus;

Antimicrobial

and

(Doria et al., 2019)

S. epidermidis

(E) -3- (3- (4-hydroxyphenyl) acryloyl) 1-octyl-1H-imidazole-3-ium (16)<smiles>O=C(/C=C/c1ccccc1)OCCCC1=CC(Cc2ccc(OC(F)(F)F)cc2)N=N1</smiles>

3- (3- (4- (trifluoromethoxy) benzyl) -3H pyrazol-5-yl) propyl cinnamate (17)

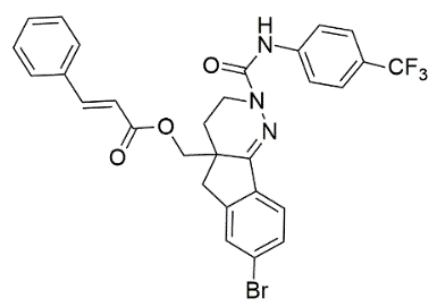

Methyl 7-bromo-2 - ((4- (trifluoromethyl) phenyl) carbamoyl) -3,4,4a, 5-tetrahydro-2H-indeno $[1,2-c]$ pyridazin-4a-yl) cinnamate (18)

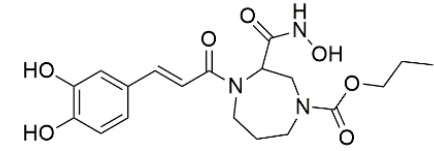

Matrix metalloproteinase inhibition
(Rathee et al., 2018)

(E) -propyl 4- (3- (3,4-dihydroxyphenyl) acryloyl) - 3(hydroxycarbamoyl) -1,4-diazepano-1-carboxylate 
<smiles>O=C(/C=C/c1ccc(OCc2ccccc2)cc1)NO</smiles>

(E) -3- (4- (benzyloxy) phenyl) $\mathrm{N}$ hydroxyacrylamide (20)

\section{Anti-hepatitis C virus Histone deacetylase (HCV) inhibition}

(Kozlov et al., 2019)

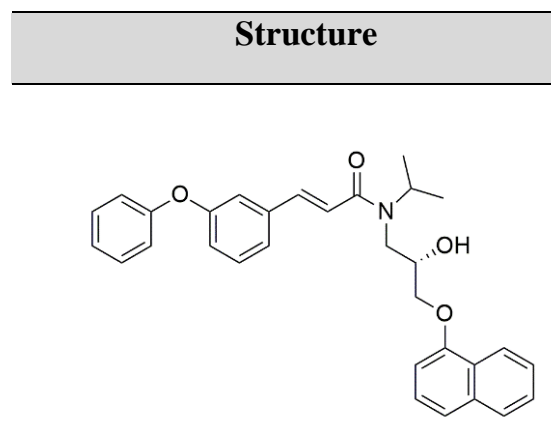

(S,E) -N- (2-hydroxy-3- (naphthalen-1-yloxy) propyl) - N-isopropyl-3- (3-phenoxyphenyl) acrylamide (21)

\section{Lipid peroxidation}

Antioxidant and anti- inhibition; lipoxygenase proteolytic inhibition; and trypsin inhibition
(Peperidou et al., 2017)

Ref.

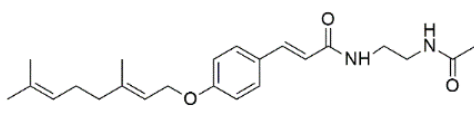

N-(2-acetamidoethyl)-3-[4-(3,7-dimethylocta-2,6dienoxy)phenyl|prop-2-enamide (22)

Antimicrobial

\section{Mycobacterium}

smegmatis

(Teixeira et al., 2020)

Enzymatic inhibition Lipoxygenase (LOX) (Landberg et al., 2020)<smiles>COc1ccc(/C=C/C(=O)NCCc2cc3ccccc3[nH]2)cc1OC</smiles>

Enzymatic inhibition

Acetylcholinesterase

(AchE)

Ghafary et al., 2020)

coumarin-amide conjugated tryptamine (24)

Some derivatives of cinnamic acid and their therapeutic properties are established in Table 1, as well as their biological target, which is differentiated by variation in the aliphatic lateral chain or substitutes in the distinct positions of the 
aromatic ring of the cinnamoyl portion, contributing to multiple mechanistic and biological actions on different living beings. The aromatic ring conjugated with the double trans link (cinnamoyl portion) fixed in the structures also performs vital functions in the therapeutic actions of this class.

Regarding inflammatory processes, cinnamic acid derivatives have been shown activity against pro-inflammatory cytokines that cause rheumatoid arthritis, asthma, and chronic obstructive pulmonary diseases. In addition, among the inflammatory biological markers, tumor necrosis factor-alpha (TNF- $\alpha$ ), interleukin-6 (IL6), and interleukin-1beta (IL-1 $\beta$ ) activities was remarkable affected by $p$-hydroxycinnamic acid (5) (Kumar et al., 2019).

Whilom known in the oriental medicine for the treatment of epilepsy, plant species as Acori Tatarinowii and Polygala tenuifolia have been newly proven to contain significant amount of the active compound $\alpha$-asaronol, which has been used as starting material on the synthesis of a CAD with pronounced effect on this disease.

Likewise, insecticidal activity of Ocimum gratissimum and Vitellaria paradoxa were evaluated by Buxton et al., (2019), who identified CAD actives, featuring among them methyl cinnamate and sitosterol, whose have been synthesised in order to assess the environmental feasibility of these compounds.

Thereby, these molecules and other CAD's might display an great alternative on the synthesis of new bioactive compounds within the scope of polypharmacology, comprising both design and synthesis of active compounds containing different pharmacophoric groups, whose promote activity against different pathophysiological pathways.

\subsection{The biosynthesis of cinnamic acid and its derivatives in plant species}

CA (1) and its derivatives are both biosynthesised by plants via the shikimic acid (SHA) pathway, as well as other secondary metabolites, such as lignins, isoflavonoids, flavonoids, stilbenes, anthocyanins, and tannins (Vogt, 2010; Ghosh et al., 2012). However, the vast majority of these metabolites have mixed biosynthetic routes, with the acetate route being added. It is noteworthy that SHA, the main precursor of these compounds, comes from the pathway of primary metabolites, derived from fundamental processes, such as photosynthesis, glycolysis, and Krebs cycle (Vogt, 2010) (Figura 2).

Figure 2. Biosynthesis of shikimic acid and its derivatives.

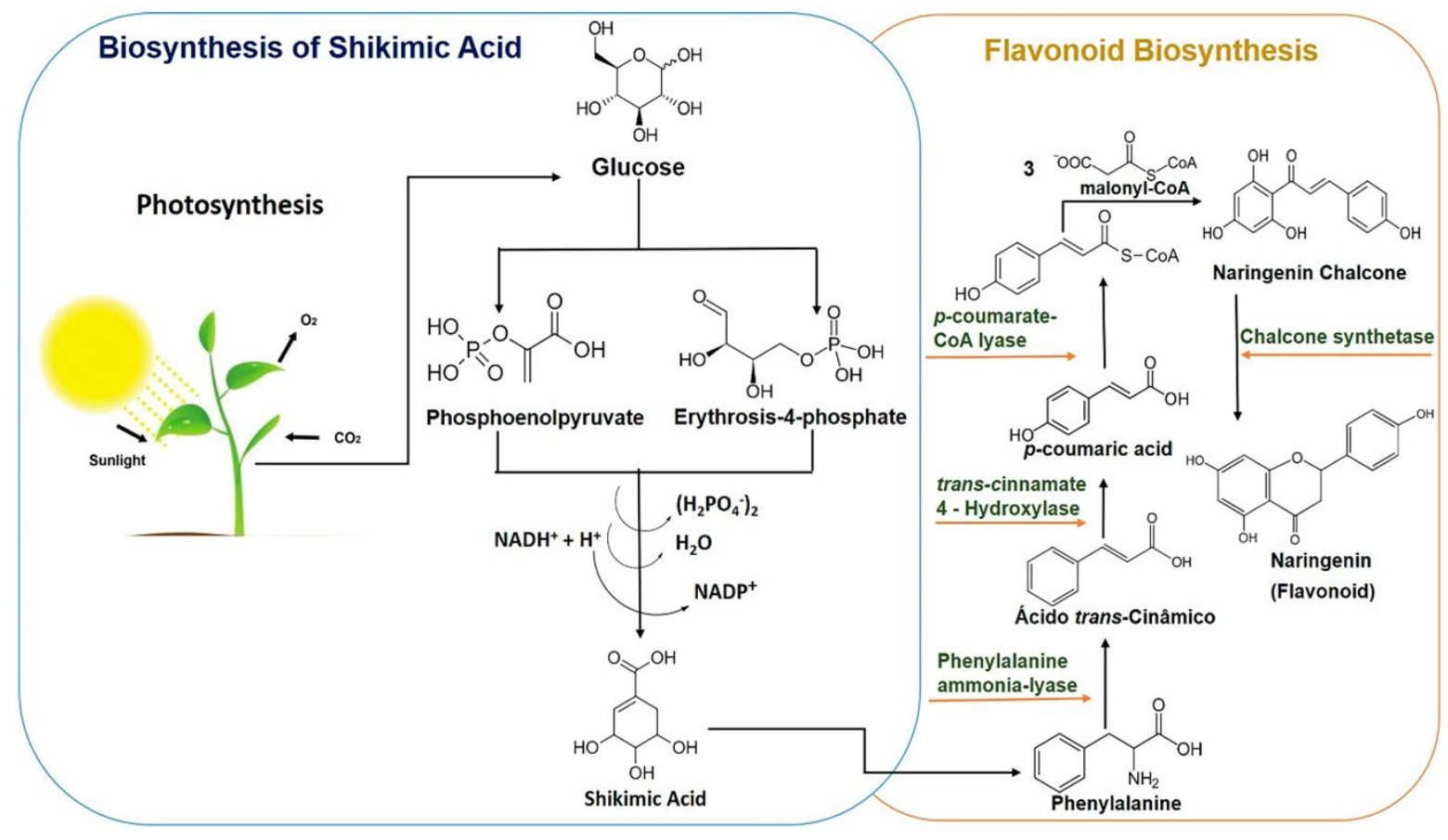

Fonte: Vogt, (2010); Ghasemzadeh \& Ghasemzadeh. (2011); Ghosh et al., (2012). 
Therefore, CAD's synthesis starts from the formation of primary metabolites by combination of phosphoenolpyruvate and erythrose-4-phosphate (products of photosynthesis) generating the precursor SHA, from which aromatic amino acids tyrosine, tryptophan, and phenylalanine are formed, as Figure 2 (Vogt, 2010; Ghasemzadeh \& Ghasemzadeh, 2011).

Hence, phenylalanine is converted to trans-cinnamic acid by activity of the enzyme phenylalanine ammonia lyase (Ghosh et al., 2012). In sequence, trans-cinnamate 4-hydroxylase enzymes convert trans-cinnamic acid into $p$-coumaric acid, which via catalysis by the enzymes $p$-coumarate-CoA lyase and chalcone synthetase and insertion of three malonyl-CoA molecules provide a chalcone (Vogt, 2010).These compounds are precursors of several phenylpropanoids, flavonoids, stilbenes, tannins, anthocyanins, and spermidines that display several pharmacological activities (Figure 2) (Gunia-Krzyżak et al., 2018; Guzman, 2014; Sharma, 2011; Sova et al., 2013; Korosec et al., 2013; Fathi et al., 2019).

Therefore, CA's are also precursors in the synthesis of cinnamic esters used in several industrial segments, such as cosmetics and pharmaceuticals, as flavourings (Gunia-Krzyżak et al., 2018; Adisakwattana, 2017). CA is recognised as an intermediate in the synthesis of many active compounds in plant species and also exhibits potent inhibition of protease enzymes, such as lipoxygenase. Several studies have shown that other acids found in nature (caffeic (2), ferulic (3), and $p$ coumaric (5) acids) and the phenolic kinematic derivatives, including those containing amide groups, display properties that contribute to the reduction and/or inhibition of free radicals and reactive oxygen species (ROS), which lead to the minimisation of the incidence of numerous degenerative, infectious, cardiovascular diseases, among others (Teixeira et al., 2020).

Furthermore, CAD's are available in several spices in different concentrations, among them coffee beans, tea, citrus fruits, tomatoes, and others, which are usually part of the human diet and crucial to the health maintenance (Belsito et al., 2007; Sharma, 2011; Sova et al., 2013; Zeng \& Lai, 2019).

\subsection{Synthetic Routes for Obtainments of Cinnamic Acid Derivatives}

Once CA's are naturally found in low concentrations, large scale use is implausible (Saito \& Lucchini, 1997; Saurabh et al., 2015). On the other hand, organic synthesis allows to obtain high amounts of molecules with simple and complex structures, inspired by nature products, which greatly contributes to the industrial market. In addition, the medicinal chemistry might detail the mechanism of action of such compounds. Among several methodologies described on the synthesis of CA and CAD's so far, Perkin, Knoevenagel and Claisen-Schmid, Olefination of Peterson and Horner-Wadsworth-Emmons, Heck, and Witting reactions are highlighted and will be discussed below.

\subsubsection{Perkin Reaction}

Willian Henry Perkin developed a reaction in the $19^{\text {th }}$ century, which is known nowadays as Perkin's reaction, which consists of the condensation of acetic anhydride and an aromatic aldehyde, under basic conditions leading to the formation of carboxylic acids, according to Scheme 1. (Gunia-Krzyżak et al., 2018).

Scheme 1. Schematic representation of the Perkin reaction.

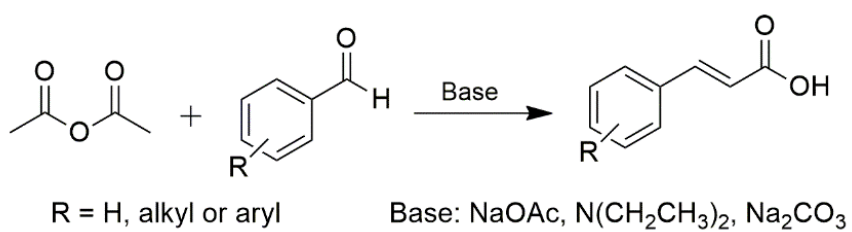

Fonte: Gunia - Krzyżak et al., (2018). 
The first synthesis of cinnamic acids was carried out applying this reaction and after that, several modifications of this reaction are described in the literature, highlighting (a) the use of microwave irradiation in presence of catalysts, such as cesium salts and small amounts of pyridine or sodium acetate trihydrate, reducing the reaction time; (b) application of recyclable solvents to replace toxic organic solvents, among them the deep eutectic solvent (DES - mixture of two compounds that contributes to the optimization of their properties), for instance, a mixture of choline chloride and urea used by Pawar et al., (2011), in Perkin's reactions in mild conditions achieving expressive yields (Table 2).

\subsubsection{Knoevenagel Reaction}

The reaction consists of the condensation between aromatic carbonyl compounds (aldehydes or ketones) and active methylene compounds (acid or its derivatives), using a base as a catalyst, frequently piperidine and pyridine, followed by acid hydrolysis (Sharma, 2011; Pontiki et al., 2014; Gunia-Krzyżak et al., 2018), according to Scheme 2.

Scheme 2. Synthesis of cinnamic acid and its derivatives through the Knoevenagel-Doebner reaction.

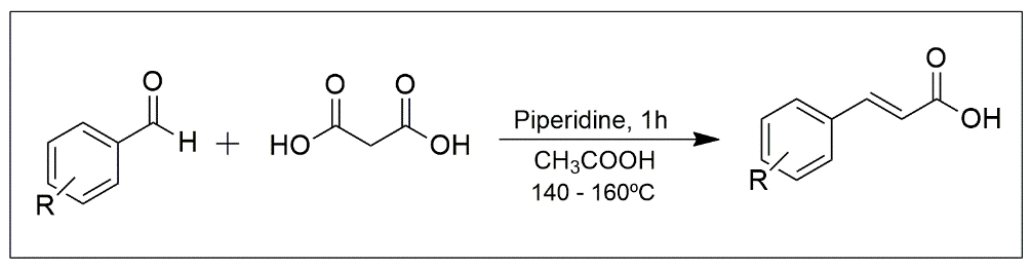

Fonte: Pontiki et al., (2014).

Knoevenagel-Doebner condensation is the main variation and consists of adding glacial acetic acid to the reaction system under reflux leading to higher yields (Scheme 2; Table 2). In addition, the classic method can be subjected to microwave irradiation in the presence of environmentally friendly catalysts such as tetrabutylammonium bromide and potassium carbonate in water, or other catalysts, such as copper oxide (organometallic), or catalytic solvent and $\beta$-alanine as a co-catalyst. However, in the last case, formation of mixture of isomers $(E: Z)$ is commonly observed (Weiner, 2009).

\subsubsection{Condensation between aldehyde and aliphatic carboxylic acid in the presence of $\mathrm{BBr}_{3}$}

Similarly to the classic Perkin's method, this synthetic approach is based on the use of aliphatic carboxylic acids and aromatic aldehydes in the presence of boron tribromide as a catalyst, acetic acid and a nitrogenous solvent system, dimethyl aminopyridine (DMAP) and pyridine (Py), under high temperatures (Scheme 3) (Chiriac et al., 2005; Gunia-Krzyżak et al., 2018).

Scheme 3. Synthesis of cinnamic acid and some DAC's with aliphatic carboxylic acid in presence of boron tribromide.

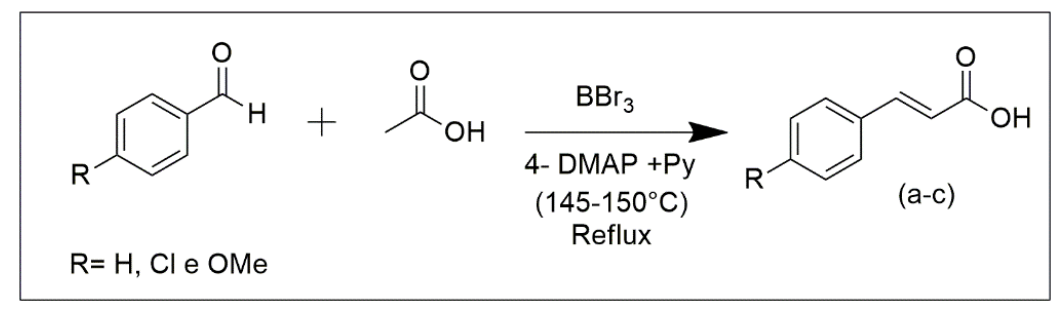

Fonte: Chiriac et al., (2005). 


\subsubsection{Claisen-Schmid Reaction}

This reaction favourably promotes the formation of cinnamic esters by condensation between aldehydes and esters in presence of metallic sodium and a mixture of toluene and an alcohol depending on the ester used (Scheme 4) (Sharma, 2011; Gunia-Krzyżak et al., 2018).

Scheme 4. Preparation of esters derived from cinnamic acid through the Claisen-Schmidt condensation reaction, followed by alkaline hydrolysis.

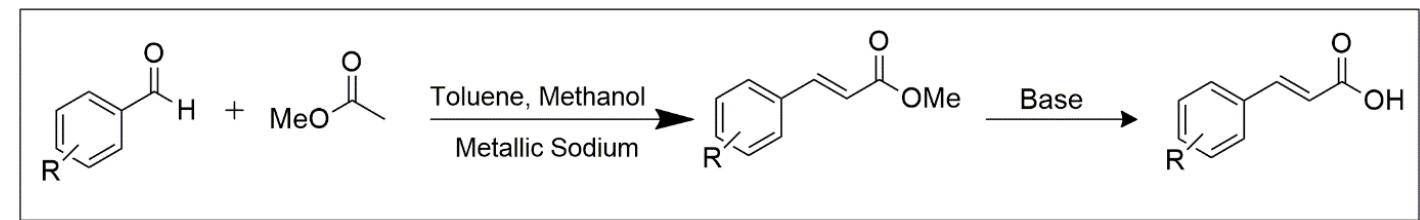

Fonte: Belsito et al., (2007); Sharma. (2011); Gunia-Krzyżak et al., (2018).

Scheme 4 presents the general synthesis of cinnamate derivatives, followed by an alkaline hydrolysis, since esters in general can be easily hydrolyzed both in synthetic and biological media by means of enzymatic catalysts to their respective precursors (Belsito et al., 2007).

\subsubsection{Peterson's Olefination Reaction}

This reaction comprehends a stereospecific method on the synthesis of alkenes by reacting an organosilicon and carbonyl compounds (Scheme 5). Additionally, using aromatic aldehydes synthesis of CAD's are observed, which the isomeric ration ( $E: Z)$ fully depends on the reaction conditions (acid or basic medium) as well as the stereochemistry of the organosilicon.

Scheme 5. Synthesis of ethyl cinnamates 1,4-disubstituted through Peterson reaction using NHC as a catalyst.

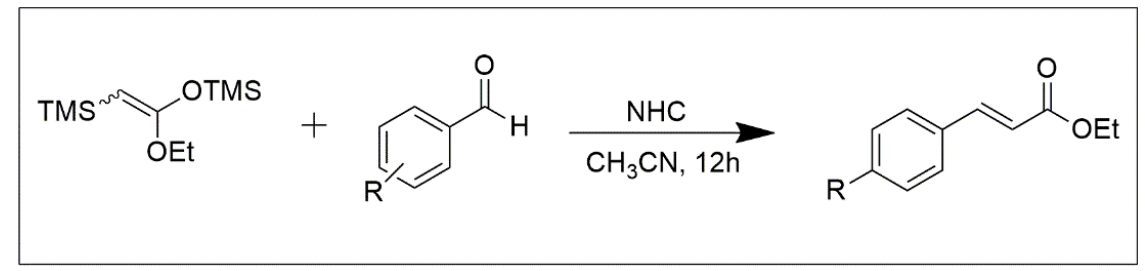

Fonte: Wang et al., (2016).

Wang et al., (2016) applied this methodology on the synthesis of CA-derived esters using acetal cetene silyl and aromatic aldehydes in the presence of $N$-heterocyclic carbene catalyst $(\mathrm{NHC})$ over $\mathrm{CH}_{3} \mathrm{CN}$, as seen in $\mathrm{Scheme} 5$.

\subsubsection{Heck Reaction}

A classic method usually applied on the synthesis of natural, chemical and pharmaceutical olefins. This method consists of reacting organic halides and alkenes in the presence of Pd-based catalyst stabilized coupled to stabilizing-types binders containing phosphine and/or nitrogen (Scheme 6) (Ren et al., 2010; He \& Cai, 2011).

Nevertheless, use of Pd as a catalyst might hinder the product extraction and purification processes. In addition, mostly of binders can be toxic, which makes industrial applications impracticable. 
Scheme 6. Preparation of ethyl cinnamates substituted in the para position through the Heck reaction over the modified catalyst.

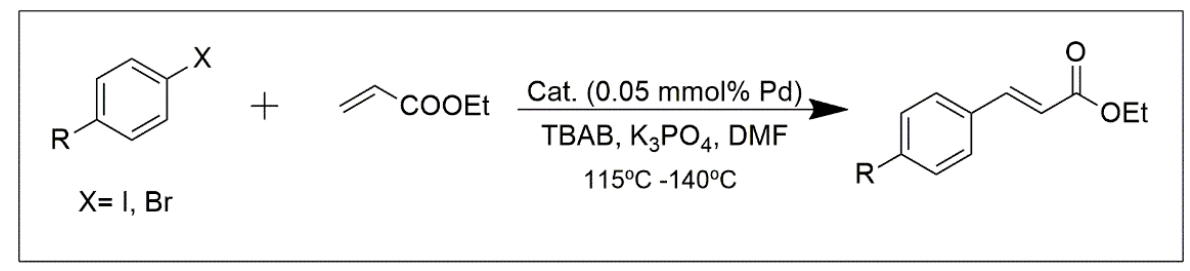

Fonte: Ren et al., (2010).

Therefore, Ren et al., (2010) proposed an improved variation of Heck reaction using a Pd-macrocyclic complex catalyst (ferrocenylimine carbene adduct palladium cycle) and tetrabutylammonium bromide (TBAB) over dimethyl formamide (DMF), as seen in Scheme 6. This reaction occurs at relatively high temperatures and leads to good yields depending on the aryl halide used (Table 2). Furthermore, this reaction can be performed on ultrasonic bath using palladium chloride as a catalyst and palladium nanoparticles (Sharma, 2011).

\subsubsection{Oxidative alkoxycarbonylation reaction}

This reaction occurs between carbazates and terminal alkenes using palladium as a catalyst under inert atmosphere (Scheme 7). This method is based on coupling ester groups to vinyl bonds to provide $\alpha, \beta$-unsaturated esters. However, due to adverse conditions and low selectivity remains as a challenging reaction (Su et al., 2013).

Scheme 7. Synthesis of cinnamic esters from oxidative alkoxycarbonylation.

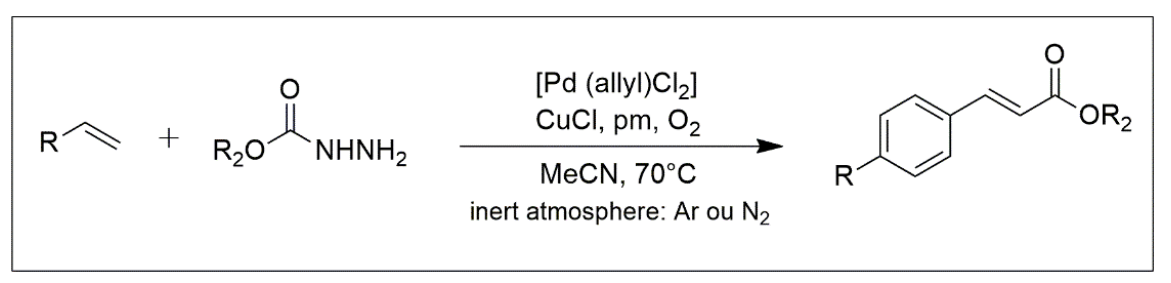

Fonte: Su et al., (2013).

The synthetic route is exemplified in Scheme 7 with some modifications proposed by Su et al., (2013), which used the simple treatment of carbazates in palladium, giving rise to alkoxycarbonylpalladiums as an intermediate, which in turn were combined with terminal alkenes generating with moderate yields the cinnamate derivatives.

\subsubsection{Witting Reaction}

The Witting reaction is based on the use of phosphorus ylide and carbonyl compounds, either ketones or aldehydes (Scheme 8). Depending on the ylide, the reaction can be stereospecific. Once stabilized ylide is used leads predominantly to thermodynamic isomer $(E)$, otherwise kinetic isomer $(Z)$ is mostly formed (Lao \& Toy, 2016). Although the reaction is considered conventional, poor atomic savings and laborious purification discourages the large-scale application (Wadsworth \& Emmons, 1961; Lao \& Toy, 2016). 
Scheme 8. Formation of cinnamic acid from the Witting reaction.

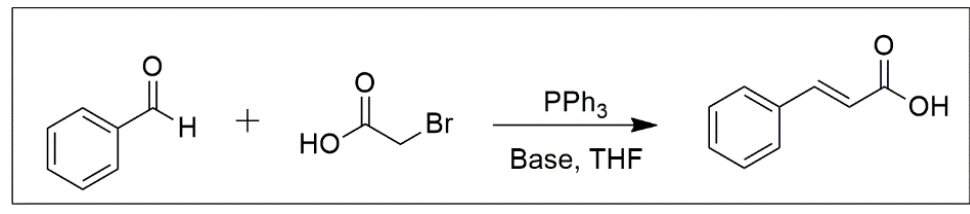

Fonte: Lao \& Toy., (2013).

\subsubsection{Aldol Condensation Reaction based on titanium enolate}

Another method is aldolic condensation, which consists of reacting acetic acid or allyl acetate-based titanium enolate with aldehydes (Scheme 9, Table 2). This methodology provides good yields towards the formation of CA and CAD's displaying trans geometry in mild conditions (Scheme 8, Table 2) (Sharma, 2011; Augustine et al., 2014).

Scheme 9. Synthesis of cinnamic acid derivatives from $\mathrm{TiCl}_{4}$ mediated aldol condensation.

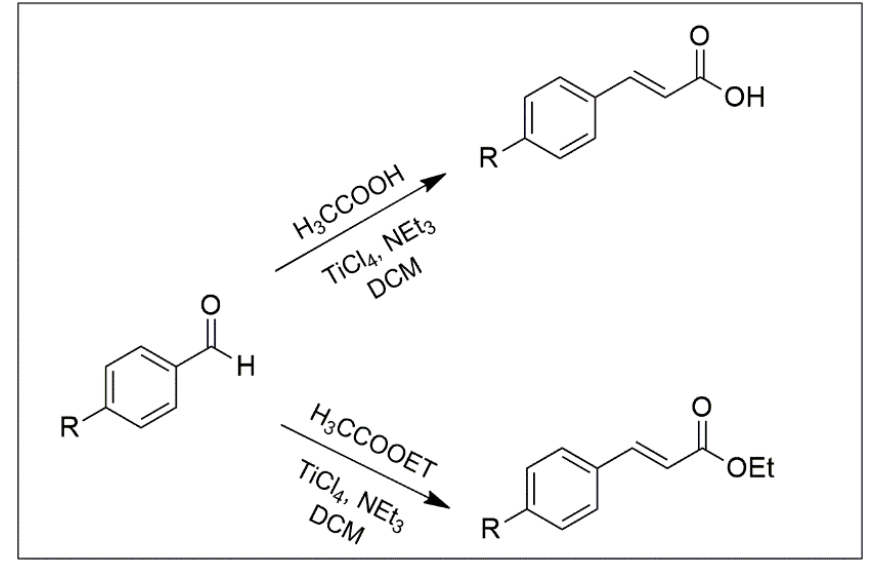

Fonte: Augustine et al., (2014).

\subsubsection{Horner-Wadsworth-Emmons Reaction (HWE)}

The olefin reaction of (HWE) is a very effective method on the formation of $\alpha, \beta$-unsaturated esters. This reaction consists of base-mediated olefination of aldehydes and ketones by ketophosphonates on the formation of CA and CAD's, conforme Esquema 10 (Sano et al., 2007). Similarly to Wittig reaction, the stereoselective ration E/Z strongly depends on the phosphonate group (Wadsworth \& Emmons, 1961; Sano et al., 2007).

Scheme 10. Synthesis of cinnamic acid through the HWE Olefination reaction.

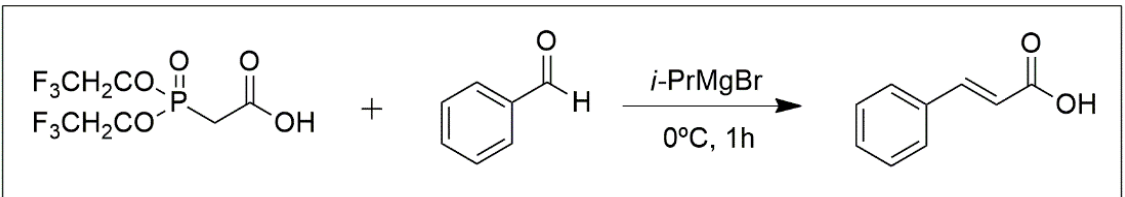

Fonte: Sano et al., (2007).

Comparing to Wiitig reaction, HWE reaction presents several advantages, highlighting (a) the stabilized ketophosphonate-based carbanion, which is considered more nucleophilic than phosphorus ilids; (b) ketophosphonates are inexpensive compared to phosphonium salts and readily react with aldehydes and ketones under mild conditions, and (c) 
noteworthy, the by-product formed is a dialkyl phosphate, which is water soluble easily separated form the product, consequently improving the purification process (Wadsworth \& Emmons, 1961).

Notwithstanding the above, formation of CAD's via HWE reaction are described such as that described by Nishikawa et al., (2013), in which using phosphoryl ethyl-2- [bis-(2-isopropylphenox)acetate] obtained cinnamic esters with Zconfiguration in good yields. Alike, Sano et al., (2003) applied bis-(2,2,2-trifluoroethyl-phosphonoacetic acid) using the Grignard reagent ( $i$-prMgBr) as a catalyst (Scheme 10) to obtain thermodynamic CA's in good yields with $E$-configuration (Table 2).

Table 2. The most used reactions in the synthesis of cinnamic acid and its derivatives.

\begin{tabular}{|c|c|c|c|c|c|}
\hline $\begin{array}{l}\text { Types of } \\
\text { reaction }\end{array}$ & Compound & Advantages & Yield (\%) & Disadvantages & Ref. \\
\hline $\mathbf{1}^{\mathrm{a}}$ & Cinnamic Acid & $\begin{array}{l}\text { The use of non-toxic and } \\
\text { biodegradable solvents. } \\
\text { Mild reactionary } \\
\text { environment. }\end{array}$ & $\begin{array}{l}60 \\
92\end{array}$ & $\begin{array}{c}\text { Unviable to } \\
\text { substituents with } \\
\text { mesomeric effect; } \\
\text { It does not react } \\
\text { with enolizable } \\
\text { aldehydes. }\end{array}$ & (Pawar et al., 2011) \\
\hline 2 & Cinnamic Acid & $\begin{array}{l}\text { The use of organo- } \\
\text { catalysts, which are } \\
\text { stable, inexpensive and } \\
\text { easy to obtain. }\end{array}$ & 80 & $\begin{array}{c}\text { Use of organic } \\
\text { solvent in } \\
\text { appreciable } \\
\text { ammount; } \\
\text { Extended reaction } \\
\text { time; } \\
\text { Use of carcinogenic } \\
\text { bases and high } \\
\text { temperatures. }\end{array}$ & $\begin{array}{c}\text { (Martínez-Soriano et } \\
\text { al., 2015) }\end{array}$ \\
\hline 3 & $\begin{array}{l}\text { The reaction } \\
\text { takes place in } \\
\text { one single step } \\
\text { (one-pot). }\end{array}$ & Cinnamic Acid & 65 & $\begin{array}{c}\text { Use of carcinogenic } \\
\text { bases; } \\
\text { Low yield in } \\
\text { electron donor } \\
\text { groups; } \\
\text { The use of high } \\
\text { temperatures. }\end{array}$ & (Chiriac et al., 2005) \\
\hline
\end{tabular}

control;

Makes use of stabilized

and reactive carbaniums
There is no atomic

(Sano et al., 2007)

$$
\text { economy. }
$$

\section{Types of Compound}

Advantages

Ref. 


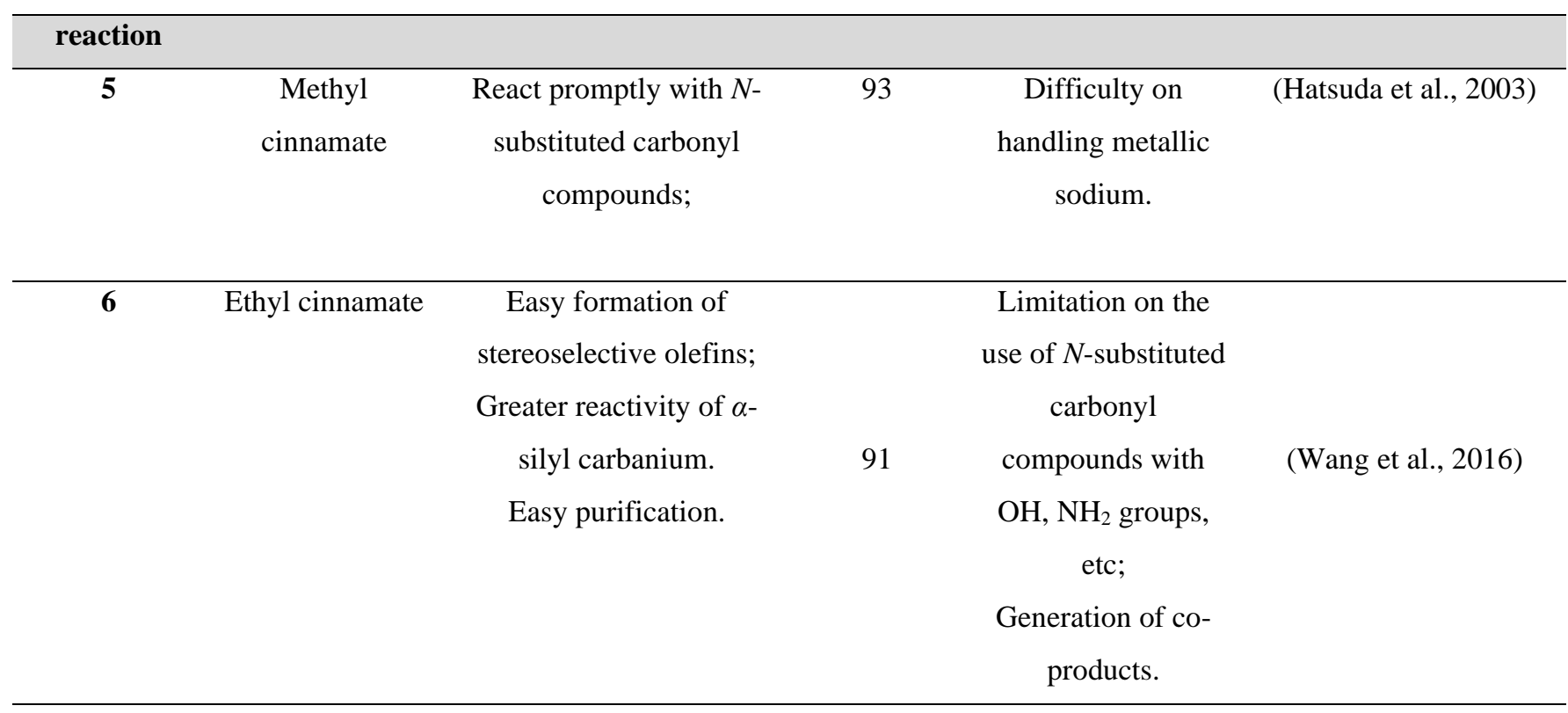

The use of toxic

Greater atomic economy catalysts;

7

Ethyl cinnamate

compared to carbonyl

78

Low selectivity and

(Su et al., 2013)

olefination.

restriction to certain

substrates.

8

Cinnamic acid

The use of titanium

98

enolate favors the

Use of toxic

(Augustine et al.,

Ethyl cinnamate

formation of

99

catalyst

2014)

stereoselective products.

The use of toxic

The use of

ethyl $p$ -

cyclopalladium promotes

98

9 nitrocinamate

and structural versatility.

and expensive

catalyst.

(Ren et al., 2010)

Difficulty in the

purification

process.

$\mathbf{1}^{\mathrm{a}}$ : Classic Perkin Reaction; 1 $\mathbf{1}^{\mathrm{b}}$ : Modified; 2: Knoevenagel Reaction; 3: Condensation between carbonyl compounds using BBr3; 4: HWE Reaction; 5: Claisen Schmidt Reaction; 6: Peterson Olefination; 7: Oxidative alkoxycarbonylation; 8: Aldol condensation based on titanium enolate; 9: Heck Reaction.

Fonte: Autores (2021).

The synthesis of CA and CAD's through the methodologies exposed above were described for large-scale production. Table 2 shows yields of some cinnamic acid derivatives obtained from the main synthetic routes recently used, which brings a series of advantages and disadvantages on the formation of these compounds. Based on these, depending on conditions and available equipment of each industrial sector, a different synthetic approach toward the formation of CAD's should be selected. Therefore, organic synthesis has been displaying a crucial role on the formation of CA and CAD's, once observing the number of synthetic methodologies which have been developed and optimized in expressive yields for that proposal. 


\subsection{Structure-Activity Relationship (SAR)}

The biological activities of CA and CAD's can be explained according to interactions with key molecular targets present in living organism. The CA presents three main reactive sites: aromatic ring substituent, carboxylic acid function, and conjugated olefin (Figure 3) (De et al., 2011).

Figure 3. Reactive sites of the cinnamic acid structure.

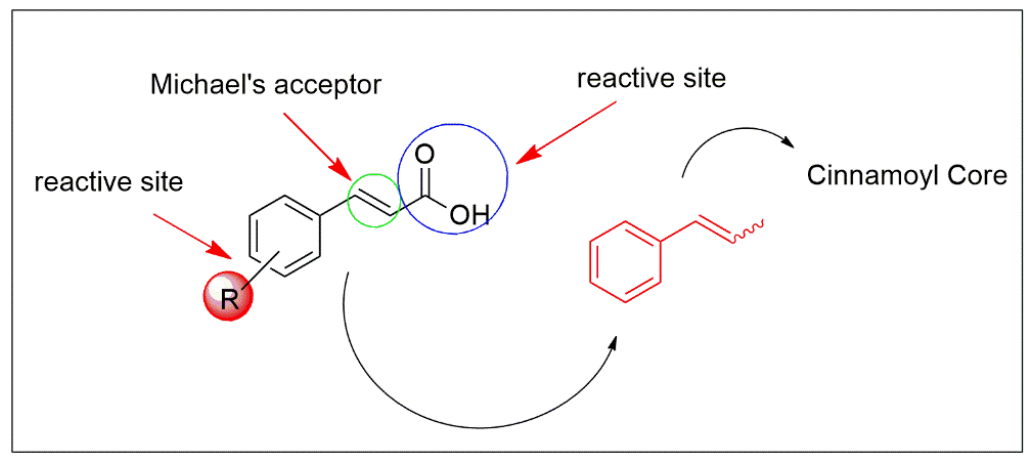

Fonte: De et al., (2011).

Hence, CA structure is considered versatile and the cinnamic skeleton is an attractive structure towards the development of new antimicrobial, hepatoprotective, antioxidant, antineoplastic agents, enzyme inhibitors, and others (Sharma, 2011; Guzman, 2014). Therefore, several CAD's have been synthesised preserving the cinnamoyl nucleus (Pontiki et al., 2014).

\subsubsection{Enzyme inhibition}

Several biological tests have been performed using CA and CAD, highlighting the enzymatic inhibition reported by Cui et al., (2016), which was verified the inhibitory activity of $p$-chlorocinnamic (27) and $p$-nitrocinnamic (28) acids (Figure 4) against tyrosinase (crucial enzyme on melanin biosynthesis in plants and animals). The results for the inhibitory concentration for $50 \%\left(1 \mathrm{C}_{50}\right)$ indicates that both $p$-chlorocinnamic acid $(0.477 \mathrm{mM})$ and $p$-nitrocinnamic acid $(0.521 \mathrm{mM})$ were more active than $\mathrm{CA}, 1 \mathrm{C}_{50}$ of $2.10 \mathrm{mM}$ (Cui et al., 2016).

Figure 4. Results of enzymatic inhibition of cinnamic acid derivatives against enzyme tyrosinase.

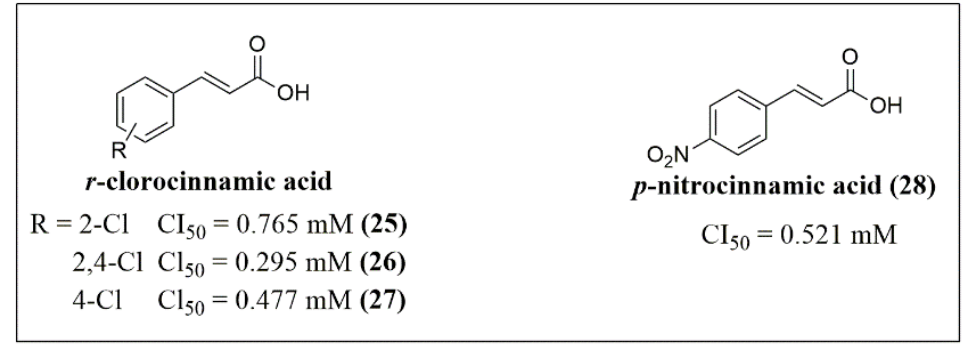

Fonte: Hu et al., (2013); Cui et al., (2016).

Molecular docking studies revealed that $p$-chlorocinnamic acid (27) binds to tyrosinase interacting with eleven amino acid residues $\left(\mathrm{His}^{61}, \mathrm{His}^{85}, \mathrm{His}^{259}, \mathrm{Asn}^{260}, \mathrm{His}^{263}, \mathrm{Phe}^{264} \mathrm{Met}^{280}, \mathrm{Ser}^{282}, \mathrm{Val}^{283}, \mathrm{Phe}^{292}\right.$, and $\mathrm{His}^{296}$ ). Furthermore, noncompetitive inhibitor was shown via non-direct enzymatic inhibition, which might be related to the fact that chlorine substituent forms no complex with copper ion present in the enzyme (Park et al., 2005; Cui et al., 2016). 
In addition, results reported by Hu et al., (2013), and Gunia-Krzyżak et al., (2018) showed the effect of chlorine substituent on the most varied positions of cinnamoyl group's aromatic ring against tyrosinase. Such studies indicate that the presence of two chlorines in orto and para positions implies a more pronounced inhibiting effect, presenting an $\mathrm{IC}_{50}$ value of $0.295 \mathrm{mM}$ (26), while the 2-chlorocinnamic acid (Figure 4) (25), an $\mathrm{IC}_{50}$ of $0.765 \mathrm{mM}$. Thus, the better activity of these compounds may be related to the effect of two halogenated substituents (Hu et al., 2013; Gunia-Krzyżak et al., 2018).

Regarding $p$-nitrocinnamic acid (Figure 4) (28), data showed that the oxygen of carboxyl group complexes with metallic ion (copper) present in the active site of the enzyme, supporting the result regarding the chelation ion capacity test. However, the authors assumed that the acid functionality binds to a different site than the active site. In addition, carbonyl oxygen could be interacting with two histidine residues ( $\mathrm{His}^{259}$ and $\mathrm{His}^{296}$ ) on the enzyme, supposing to be a mixed inhibitor (Cui et al., 2016).

The inhibiting activity of other acids against this enzyme, such as p-coumaric acid (5), used to hyperpigmentation treatment is also described. The interaction occurs via two tyrosinase substrates, tyrosine and 3,4-dihydroxyphenylalanine (Gunia-Krzyżak et al., 2018).

Furthermore, Peperidou et al., (2017) showed that cinnamoyl structure is crucial for multi-target compounds preparation, highlighting drugs such as atenolol and propranolol coupled to the cinnamoyl group, which resulted in remarkable synergistic effect on trypsin inhibition and a high-antioxidant performance, considering the action of lipid antiperoxidation in combination with the inactivation of lipoxygenase, responsible for lipid degradation, contributing to the formation of radical species (Pontiki et al., 2014; Peperidou et al., 2017).

Furthermore, Zhang et al., (2019) highlight the growing interest in multi-functional drugs with various approaches to synergistic effects, of which the CA's stand out for presenting properties similar to such drugs, with satisfactory pharmacokinetic characteristics for biological systems and ease functional derivatization. This favors the optimization of the broad-spectrum of CAD's, such as the application of amides as protein inhibitors.

In this context, Passos et al., 2020 have demonstrated the effect of a series of acrylamides derived from cinnamic acid with activity against Chikungunya virus (CHIKV), highlighting the (E)-3-(3-chlorophenyl)- $N$-phenylacrylamide (29) (Figure 5), with an inhibition rate of $49.1 \%$ (Passos et al., 2020). This antiviral action is possibly related to the inhibition of mature E3-E2-E1 glycoproteins complex present in CHIKV, where the flow cytometry revealed that the CHIKV-positive host cells was reduced from 74.8 to $0.91 \%, 48$ hours post-treatment by using compound 29 at $40 \mu \mathrm{M}$ concentrations. Additionally, molecular docking studies reveal hydrophobic interactions and hydrogen bonds between the binder (compound 29) and amino acid residues (Leu ${ }^{42}, \mathrm{Val}^{179}, \mathrm{Tyr}^{180}, \mathrm{Asn}^{264}, \mathrm{Pro}^{265}$, Val ${ }^{266} \mathrm{e}$ Tyr122) in the referred glycoproteins' complex (Passos et al., 2020).

Moreover, in vitro studies performed by Ghafary et al., (2020) have demonstrated expressive enzymatic inhibition of coumarin-amide conjugated tryptamine (30) (Figure 5) against acetylcholinesterase (AChE) and butyrylcholinesterase $(\mathrm{BuChE})$, in which by in silico studies it has been proven that the triptamine and cinnamoyl pharmacophoric groups present interactions with amino acid residues in anionic and catalytic peripheral site of AChE, which shows the potentiality of CAD's as promising agents for the treatment of neurodegenerative diseases such as Alzheimer (Ghafary et al., 2020). 
Figure 5. Results of viral and protein inhibitions of cinnamic acid derivatives.

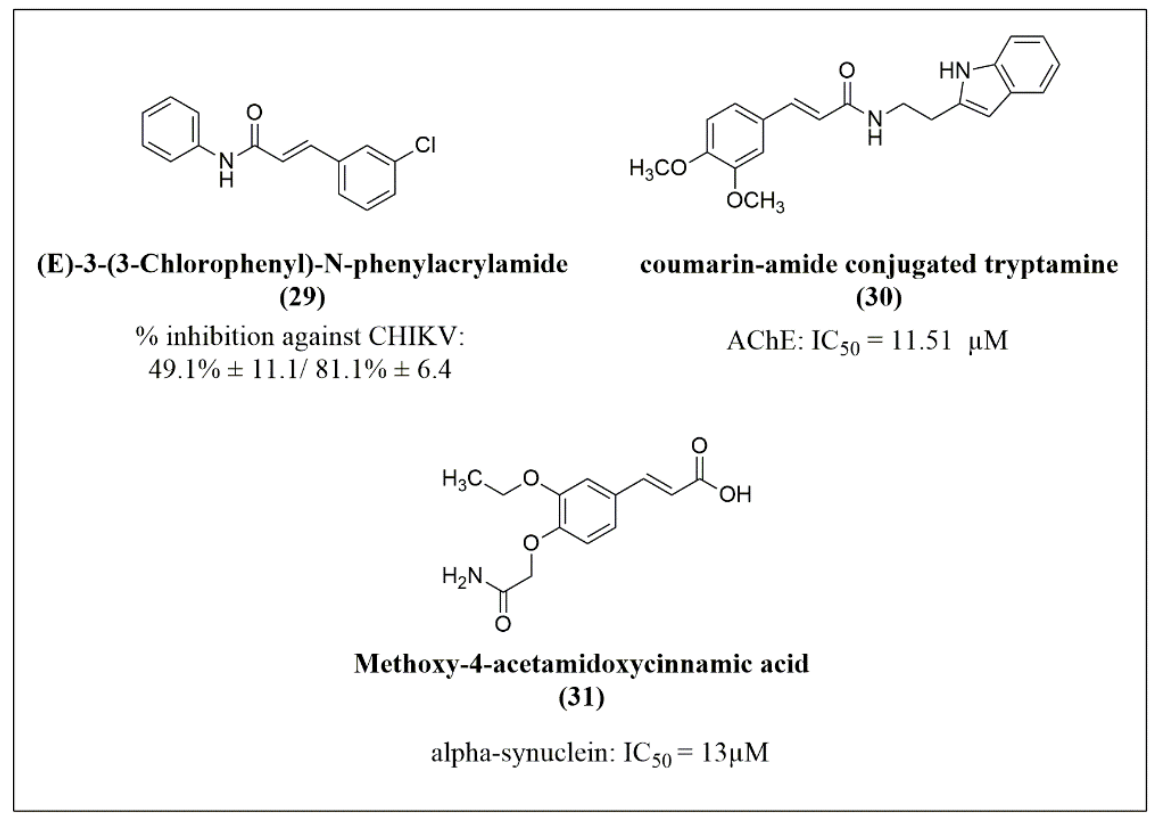

Fonte: Ghafary et al., (2020); Passos et al., (2020); Medvedeva et al., (2020).

Besides, according to Medvedeva et al., (2020), CAD's can act in the prevention of pathological transformations of amylogenic proteins, in particular alpha-synuclein, whose fibrillar form is the main cause of its aggregation and consequent induction to the development of Parkson's disease, as it was observed by utilising derivatives of 3,4-dimethoxycinnamic acid, highlighting methoxy-4-acetamidoxycinnamic acid (31) (Figure 5), which prevented the association of alpha-synuclein and stabilization of its non-toxic conformation, with an $\mathrm{IC}_{50}$ of $13 \mu \mathrm{M}$ (Medvedeva et al., 2020).

Figure 5 shows the set of acrylamides (29 and 30) and cinnamic derivatives with the most promising acid functionalization (31) of the collections synthesized by Passos et al., (2020); Ghafary et al, (2020) and Medvedeva et al., (2020), representing the cinnamic derivatives with actions of enzymatic inhibitions, leading to highlight that the amides and acid functionalizations can be good fragments options for the interaction with the enzyme to be studied.

In addition, CAD's inhibited other enzyme classes, such as benzoate 4-hydroxylase, present in several microorganisms, such as fungi and bacteria and matrix metalloproteinase (MMPS) found in tumor cells, which are produced and secreted (Shi et al., 2012; Korošec et al., 2013).

\subsubsection{Antimicrobial action}

The antimicrobial activity of CAD's had been extensively investigated. Usually, the studies are based on the inhibitory action against enzymes present in microorganisms (e.g. fungi, bacteria and protozoa), compromising the development and inducing death. Thereby, studies reveal that the compromise in the growth of fungi by CAD is directly related to the interaction with the enzyme benzoate 4-hydroxylase responsible for aromatic detoxification (Koros`ec et al., 2013; Guzman, 2014; Chen et al., 2018).

Hence, studies described in the literature revealed that CA's naturally found (Figure 1) displayed antimicrobial activities (antifungal and antibacterial). Although CA (1) showed less active against Aspergillus niger and Streptococcus pyogenes with a MIC (minimum inhibitory concentration) of $844 \mu \mathrm{M}$ for both species, ferulic acid (3) presented great result against S. pyogenes and p-coumaric acid (5) against A. niger (Table 3) (Bisogno et al., 2007; Georgiev et al., 2012). 
Table 3. Result of the antimicrobial activity of some cinnamic acids.

\begin{tabular}{ccc}
\hline Compounds & Aspergillus niger & Streptococcus \\
& ATCC 11394 & Pyogenes 10535 \\
& $($ MIC) & $($ MIC) \\
\hline Cinnamic acid (1) & $844 \mu \mathrm{M}$ & $844 \mu \mathrm{M}$ \\
\hline Caffeic acid (2) & $>1.39 \mathrm{mM}$ & $694 \mu \mathrm{M}$ \\
\hline Ferulic acid (3) & $>10 \mathrm{mM}$ & $322 \mu \mathrm{M}$ \\
\hline$p$-coumaric acid (5) & $761 \mu \mathrm{M}$ & $761 \mu \mathrm{M}$ \\
\hline
\end{tabular}

Fonte: Bisogno et al., (2007); Georgiev et al., (2012).

On the other hand, CA (1) presented the highest fungal inhibition growth against A. niger compared to caffeic (2) and ferulic (3) acids. Additionally, CA showed great result against $S$. aureaus a zone of growth inhibition diameter of $16 \mathrm{~mm}$ compared to the other acids ( $\mathbf{2}, \mathbf{3}$ and $\mathbf{5}$ ) with values of 10, 13, and $14 \mathrm{~mm}$, respectively (Jitareanu et al., 2013).

Accordingly, antimicrobial activity of CA (1) is highly related to the cinnamoyl nucleus (Figure 3), and the activity improves when substituents are added to the phenyl ring. Studies carried out with the bacteria Escherichia coli proved this when CA presented a MIC of $6.75 \mathrm{mM}$, whilst incorporating electron withdrawing groups such as $\mathrm{Cl}$ and $\mathrm{NO}_{2}$ at para position, both improved the antimicrobial activity presenting MIC values of 708 and $794 \mu \mathrm{M}$ (Figure 6, (27) and (28)), respectively (Tonari et al., 2002; Narasimhan et al., 2004; Guzman, 2014). However, adding electron donating groups led to better results, highlighting the methoxy substituent on para position presented a MIC of $164 \mu \mathrm{M}$ (Guzman, 2014; Passos et al., 2020; Medvedeva et al., 2020). Apparently, presence of two effects (mesomeric and polarity) of p-methoxycinnamic acid (32) is responsible to this result (Tonari et al., 2002; Narasimhan et al., 2004).

Likewise, described results of $r$-coumaric acid proved the influence of phenyl position substituent, which showed significant activity against E. coli, S. aureus, Salmonela typhimurium, and Lactobacillus rhamnosus compared to CA (Sharma, 2011; Guzman, 2014).

These acids (Figure 6) (33-35) were evaluated against Mycobacterium tuberculosis, which presented variation related to the hydroxyl group position on the aromatic ring, featuring o-coumaric acid (Figure 6) (33) as the most active with a MIC value of $122 \mu \mathrm{M}$, while $m$-cumaric and $p$-cumaric acids (Figure 5) (34,35) exhibited MIC value of 366 and $244 \mu \mathrm{M}$, respectively. These values were lower compared to CA (1), MIC $675 \mu \mathrm{M}$ (Figure 1) (Rastogi et al., 2008; Guzman, 2014).

Furthermore, depending on the living organism subjected to the test, functionalization strongly contributed to increasing or reduction of the biological activity. For Instance, antimicrobial activity is notably observed against amides and cinnamic esters compared to the respective precursors (cinnamic acids) using Aspergillus niger species (Figure 6) (Guzman, 2014). 
Figure 6. Structure of cinnamic acid derivatives with antimicrobial action.

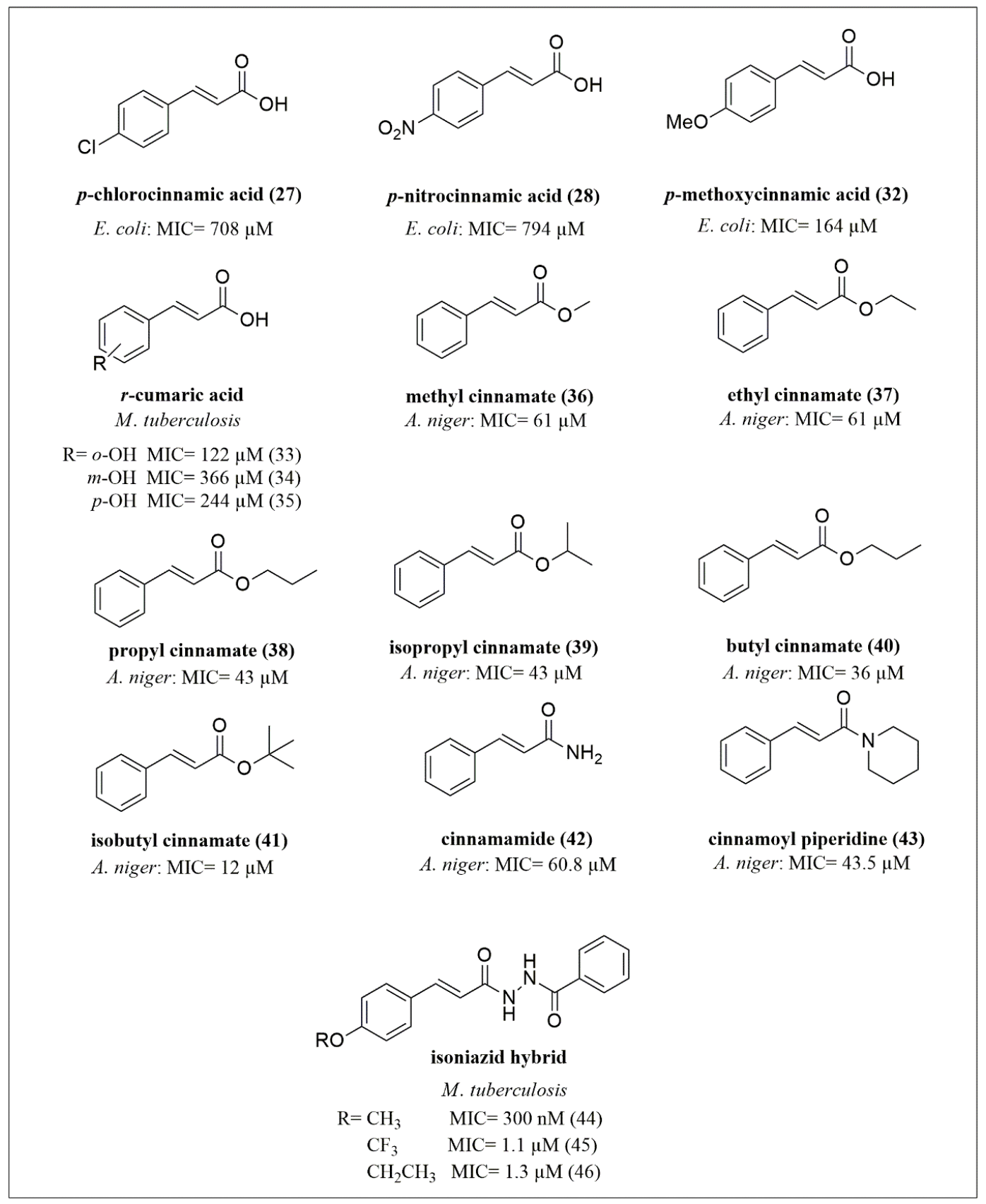

Fonte: Tonari et al., (2002); Narasimhan et al., (2004); Rastogi et al., (2008); Guzman. (2014).

Moreover, side-chain of esters and cinnamic amides particularly contributed to the increase of the active, such as results obtained by using isobutyl cinnamate (Figure 6) (41), presenting a MIC of $12 \mu \mathrm{M}$ compared to methyl (36) and ethyl cinnamates (37), MIC of $61 \mu \mathrm{M}$ (Narasimhan et al., 2004). Therefore, as long as the carbon side-chain from 5 carbons to so on, as minor growth inhibition of fungus is observed. Also, antibacterial activity is lower observed up to 4 carbons on the side chain of cinnamic esters (Cui et al., 2016). Regarding antifungal activity, $N$-substituents of cinnamic amides interfered on the results observed. Cinnamamide (Figure 6) (42) presented a MIC of $60.8 \mu \mathrm{M}$, while replacing the aliphatic side-chain by a piperidine cycle showed a MIC of $43.5 \mu \mathrm{M}$ (Figure 6, (43)) (Narasimhan et al., 2004).

In addition, it is necessary to emphasize other remarkable class of CAD's, such as the cinnamic hybrids, which originally obtained from the combination of two simple active molecules in order to optimize biological activities through a 
simultaneous interaction with multiple targets (Peperidou et al., 2017). For instance, $p$-methoxy-isoniazid hybrid (Figure 6) (44) displayed greater inhibitory bactericidal growth with a MIC of $300 \mathrm{nM}$. Conversely, addition of phenyl substituent groups with polarity effects promotes reduction on the activity showing lower values of MIC (De et al., 2011; Guzman, 2014). Scarcely any hybrids were performed for antimicrobial activity, however, from this results observed that the effectiveness may be related to the conjugation of the cinnamoyl system, in which this effect is usually applyed to modulate a range of activities (Guzman, 2014).

In the literature, activity of hydroxycinnamyl amides, especially 4-amino antipyridines (Figure 7) (50) against bacteria growth inhibition such as $S$. aureaus seems to be more promising than its own precursors (cinnamic acids), which presented a growth inhibition zone (IZ) up to $30 \mathrm{~mm}$. Contrarily, CA's (Figure 1) displayed better activity against some fungi, such as Candida albicans, with an inhibition zone of $30 \mathrm{~mm}$, while the respective amides showed no inhibit growth (Jitareanu et al., 2013).

Figure 7. Structure of derivatives of cinnamic acid and its antimicrobial activity.

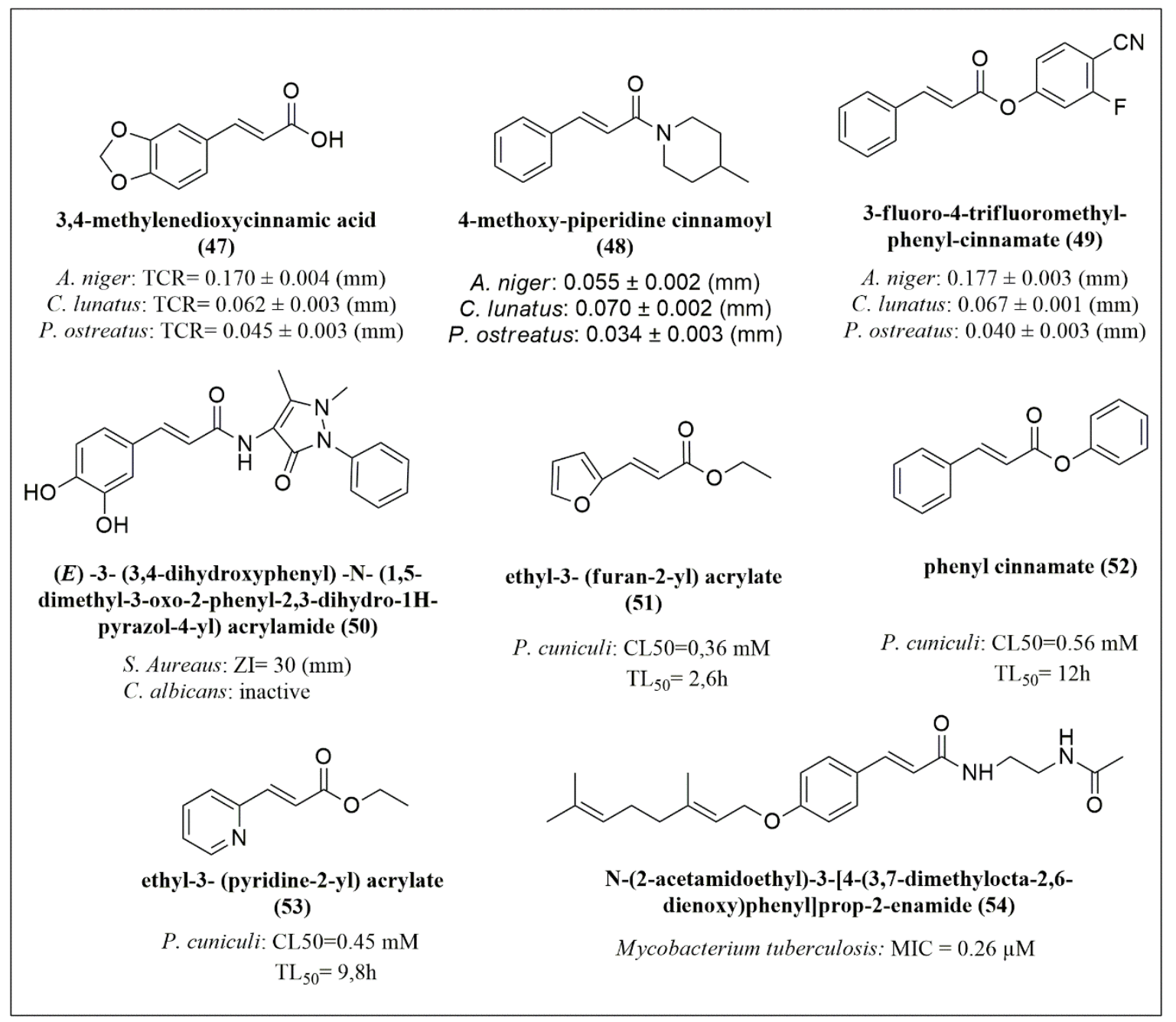

Fonte: Jitareanu et al., (2013); Korošec et al., (2013); Chen et al., (2018); Texeira et al., (2020).

The antifungal activity of CAD's is related to enzymatic inhibition. In a study developed with three types of fungi ( $C$. lunatus, A. niger, and P. ostreatus) observed inhibition of the enzyme 4-hydroxylase-benzoate CYP53A15 by some CAD's (Korošec et al., 2013). Molecular modelling analysis showed that the phenyl group of cinnamoyl structure and hydrogen 
interactions present at the enzyme active site (CYP53A15) were crucial for developing the antifungal activity (Koros ec et al., 2013). Among the derivatives tested, 4-methoxy-piperidine cinnamoyl (Figure 7) (48), 3-fluoro-4-trifluoromethylphenylcinnamate (Figure 7) (49) and 3,4-methylenedioxycinnamic acid (Figure 7) (47) showed highest fungal growth inhibition (> 75\%), which presented to display the most pronounced result regarding radial growth rate (RCR) for A. niger and $P$. ostreatus species with values of $0.055 \pm 0.002$ and $0.034 \pm 0.003 \mathrm{~mm}$, respectively. Regarding to C. lunatus species, 3,4methylenedioxycinnamic acid (47) with a RCR $0.062 \pm 0.003 \mathrm{~mm}$ were the most promising (Figure 7) (Koros ec et al., 2013).

CA also inhibited the enzyme showing less pronounced performance (RCR $0.219 \pm 0.014 \mathrm{~mm}$ ) (Koros ${ }^{` e c}$ et al., 2013). Based on this, electron withdrawing groups presented in the ring of the cinnamoyl nucleus induced higher antifungal activity.

Despite of antifungal activity, CAD's also performed antibacterial activity against species Psoroptes cuniculi. Chen et al., (2018) used a collection of CAD's (cinnamic amides and cinnamic esters) and observed superior results related to cinnamic esters, highlighting ethyl-3-(furan-2-yl)acrylate (Figure 7) (51), phenyl cinnamate (Figure 6) (52), and ethyl-3(pyridine-2-yl)acrylate (Figure 7) (53) with $\mathrm{LC}_{50} 0.36$; 0.56, and $0.45 \mathrm{mM}$, and lethal time (LT 50 ) 2.6; 12 , and 9.8 hours. Molecular modelling analyses showed that carbonyl group is crucial for this activity and the increase or reduction is related to the alkoxyl chain length as well as the steric hindrance caused by this group. In addition, presence of $\alpha$-pyridyl or $\alpha$-furanyl groups on the cinnamic contributed to improve the activity (Chen et al., 2018).

Over the past years, the potential of CAD's as agents for the treatment of tuberculosis has been known as described by Texeira et al., (2020), who characterized in silico the relationship between molecular descriptors of various cinnamic derivatives (energetic, geometric, structural, physical-chemical, and electronic) and the biological activities against Mycobacterium tuberculosis, highlighting the compound 54 which displayed a MIC value of 0.26 $\mu$ M (Texeira et al., 2020).

\subsubsection{Antioxidant activity}

The antioxidant property is also part of the functionality of CA and CAD's that display the ability to eliminate free radicals and ROS formed by oxidative stress, which are considered etiopathogenic agents and are involved on the development of some diseases, among these heart and brain diseases stand out (Jitareanu et al., 2013; Pontiki et al., 2014). The action of these compounds occurs by inhibiting enzymes that participate in the metabolism of arachidonic acid, especially lipoxygenase. This biological catalyst contributes to the formation of bioactive lipids, free radicals, lipid peroxides and others that could lead to gene alterations and modifications of post-translational proteins related to cancer (Pontiki et al., 2014).

In recent decades, it was found that CAD's from natural sources have anti-cancer, antioxidant and others related potential activity (Jitareanu et al., 2013; Martínez-Soriano et al., 2015; Zeng \& Lai, 2019). Studies revealed that these biological activities were related to the cinnamoyl nucleus, present in the structure of this class of compounds, and hydroxyl groups, the latter being crucial for the elimination of free radicals and ROS, minimizing the oxidation of low-density lipoprotein (LDL) (Jitareanu et al., 2013; Martínez-Soriano et al., 2015).

Among the CAD's with antioxidant properties, p-coumaric (5), caffeic (2) and ferulic (3) acids stands out (Figure 1) (Pontiki et al., 2014). Studies conducted by Jitareanu et al., (2013) showed that the antioxidant activity of hydroxycinnamic acids is related to the elimination of free radicals. CA's already displays antioxidant activity with a radical elimination activity (DPPH) greater than $200 \mathrm{mM}$. However, the addition of hydroxyl groups in its structure implies a reduction in DPPH (Table 4), with caffeic (2) and p-coumaric (5) acids (Table 4) being the most active. Meanwhile, there is a more pronounced intensity for caffeic acid (2) due to the presence of two hydroxyl groups (Jitareanu et al., 2013). 
Table 4. Antioxidant activity of cinnamic acid derivatives.

\begin{tabular}{ccc}
\hline Compound & DPPH CE50 $(\boldsymbol{\mu M})$ & $\begin{array}{c}\text { Reduction power of } \mathbf{F e}^{\mathbf{3 +}} \\
\text { CE50 }(\mathbf{m M})\end{array}$ \\
\hline Cinnamic acid (1) & $>200,000$ & $>200$ \\
\hline Caffeic acid (2) & $7.70 \pm 0.0001$ & $0.12 \pm 0,01$ \\
\hline Ferulic acid (3) & $54.40 \pm 0,0002$ & $0.22 \pm 0,01$ \\
\hline$p$-Cumaric acid (5) & $12.80 \pm 0,10$ & $0.42 \pm 0,01$
\end{tabular}

Fonte: Jitareanu et al., (2013).

Studies showed that the inhibition of lipoxygenase is possibly related to the reduction of the ferric ion $\left(\mathrm{Fe}^{3+}\right)$, present in this enzyme, to $\mathrm{Fe}^{2+}$ which leads to its inactivation (Peperidou et al., 2017). The results proposed by Jitareanu et al., (2013) were consistent with such studies and reveals that caffeic acid (2) displayed more pronounced antioxidant activity with a reduction in ferric ion at $\mathrm{CE}_{50}$ of $0.12 \mathrm{mM}$ (Table 4).

It was also observed that the presence of electron withdrawing atoms in the double bond with trans geometry and the increment of another double bond (trans) increase the inhibition activity against lipoxygenase, and contribute to the elimination of free radicals. It was the case with 4-bromo-5-phenylpenta-2,4-dienoic acid (Figure 8) (56), which eliminated $100 \%$ of free radicals at a concentration of $0.1 \mathrm{mM}$, and its inhibition concentration of $50 \%$ against lipoxygenase was equivalent to $10 \mu \mathrm{M}$. Computational studies suggest that this activity is related to the interaction between carboxyl group oxygen and $\mathrm{Thr}^{792}$ and $\mathrm{Ser}^{793}$ residues (Pontiki et al., 2014).

Figure 8. Antioxidant activity based on the elimination of free radicals and inhibition of lipoxygenase.

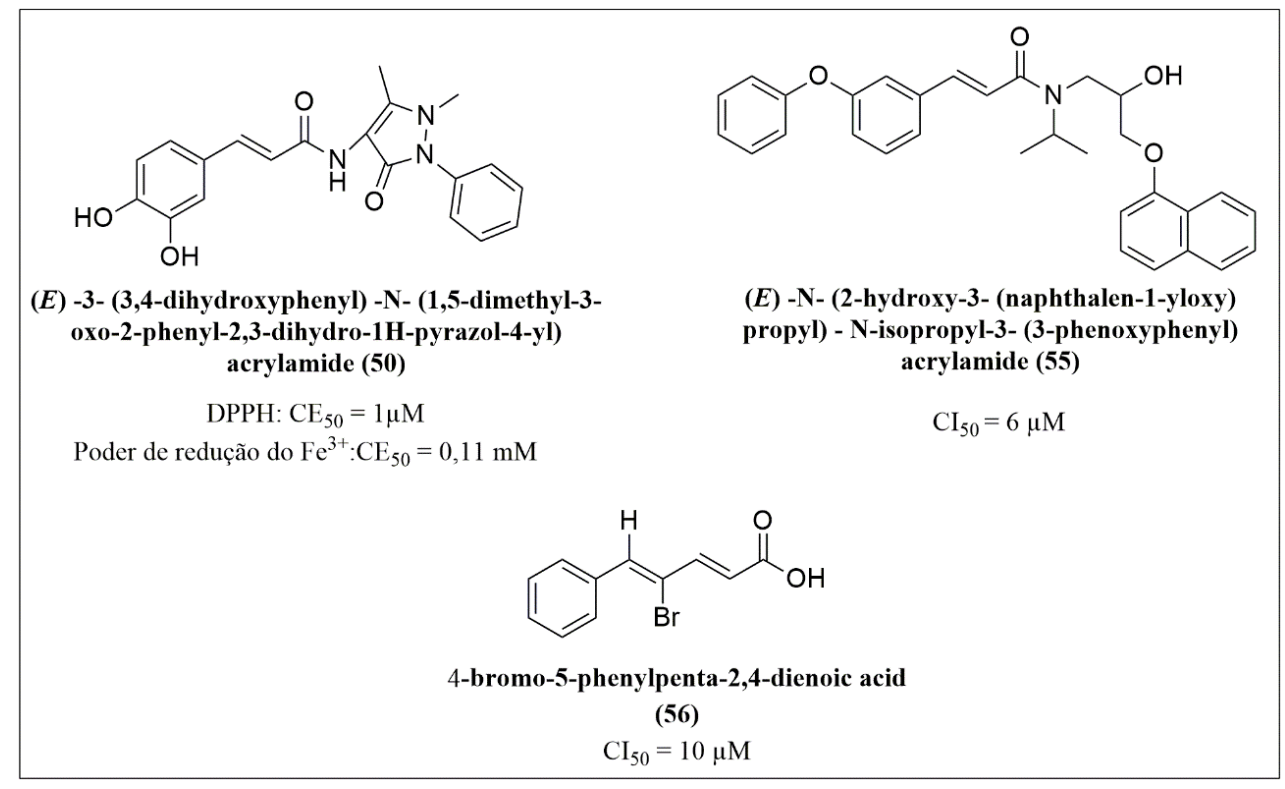

Fonte: Pontiki et al., (2014); Zhang et al., (2019).

The cinnamic amides with hydroxyl groups and an aminoantipyridine or oxydibenzene part showed better free radical scavenging activity (Figure 8, (50) and (55)) (Jitareanu et al., 2013; Peperidou et al., 2017). Molecular docking studies show that the inhibitory activity of cinnamic amide containing an oxydibenzene group (55) against lipoxygenase is related to the $\pi$ - $\pi$ 
stacking interaction with two histidine amino acid residues $\left(\mathrm{His}^{504}\right.$ and $\mathrm{His}^{999}$ ), which possibly blocks the active site of this enzyme (Peperidou et al., 2017).

Furthermore, Zhang et al., (2019) have demonstrated evidences of effective neuroprotection activity of cinnamides, mainly containing a methoxide substitutes $\left(-\mathrm{OCH}_{3}\right)$ associated to the cinnamoyl pharmacophoric group, which allows a greater cellular viability against cells injured by oxidative stress and contributes to the reduction and/or inhibition of neuronal apoptosis (Zhang et el., 2019).

Among the acrylamides derived (E)- $N$-(4-hydroxy-3-methoxybenzyl)-3-(2,4,5-trimethoxyphenyl)acrylamide $\left(\mathrm{EC}_{50}=3.26 \pm 0.16(\mu \mathrm{M})\right.$ and $\left.2.41 \pm 0.10(\mu \mathrm{M})\right)$ successfully performed against HBMEC-2/SH-SY5Y hydrogen peroxide damaged cell lines, while the compound $\mathbf{5 8}\left(\mathrm{EC}_{50}=2.59 \pm 0.31(\mu \mathrm{M}) / 5.91 \pm 0.16(\mu \mathrm{M})\right)$ displayed improved performance against HBMEC-2 cells. On the other hand, lack of methoxide group showed reduction of the neuroprotection activity (Figure 9) (Zhang et al., 2019).

Figure 9. Neuroprotection activity of DAC's against cell lines: HBMEC - 2/SH-SY5Y damaged by $\mathrm{H}_{2} \mathrm{O}_{2}$.

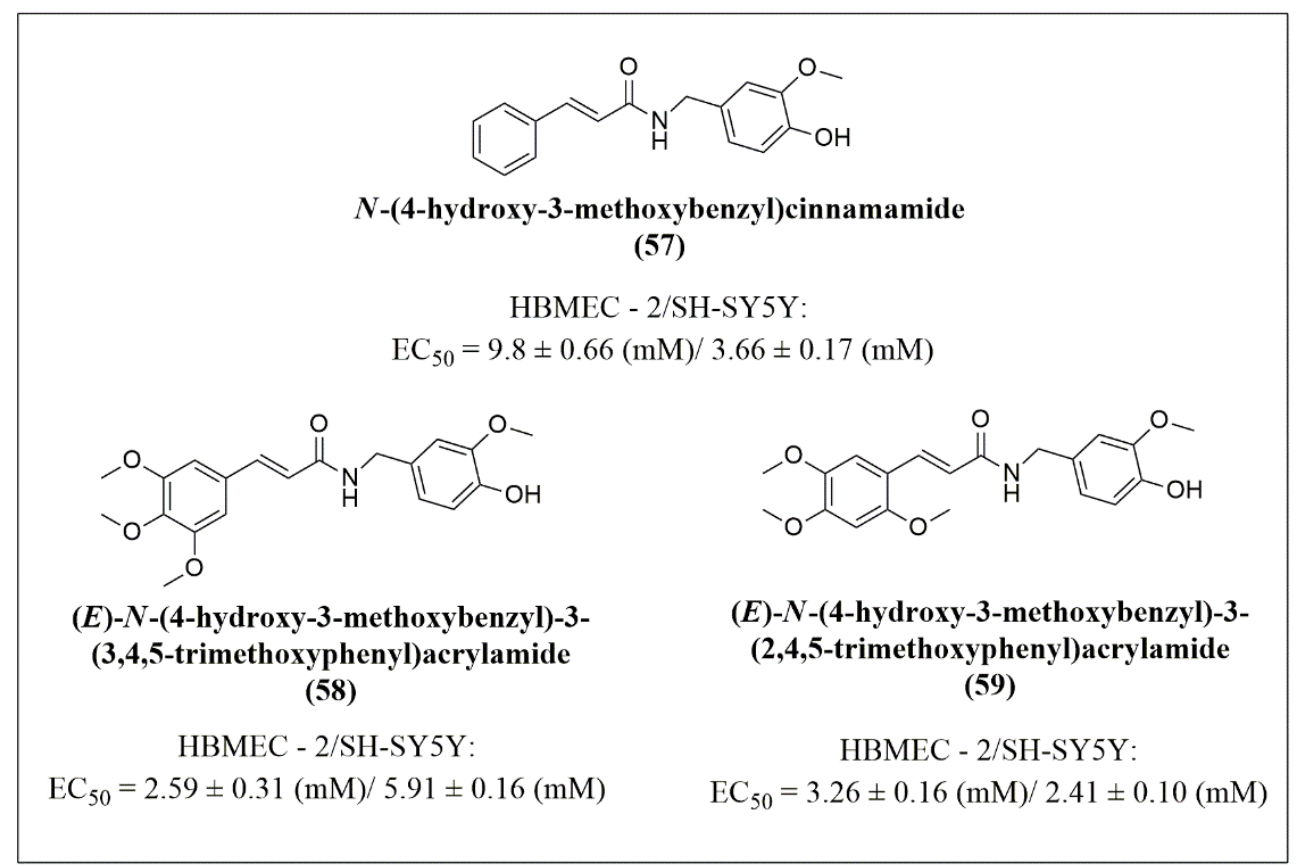

Fonte: Zhang et al., (2019).

Thus, Figure 8 and 9 present the compounds that stood out the most in the free radical scavenging study by Pontiki et al., (2014) and Zhang et al., (2019), who observed that the functionalization is acid or amide and the effect of the substituents contributed to the elimination of the reactive species of oxygen and free radicals, having a possibility of being good candidates for leading antioxidant and neural compounds.

\subsubsection{Antineoplastic activity}

As previously described, CAD's are great candidates for antioxidant action, which contributes to the reduction of degenerative diseases, such as cancer, that arise through the excessive accumulation of free radicals and reactive oxygen species. CAD's also works by eliminating carcinogenic cells, either by inhibiting enzymes such as lipoxygenase, tyrosine kinase or matrix metalloproteinase, which regulate the development and growth of tumor cells, or by another mechanism of action that leads to apoptosis (De et al., 2011; Shi et al., 2012; Sova et al., 2013; Pontiki et al., 2014). 
Most CAD's with antioxidant action also have anticancer potential. For example, 4-bromo-5-phenylpenta-2,4-dienoic acid (Figure 8) (56) inhibited several tumor strains, such as colon of the uterus (HT-29, $\left.\mathrm{Cl}_{50}=54 \pm 1.1 \mu \mathrm{M}\right)$, breast $(\mathrm{MDA}-$ MB-231, $\left.\mathrm{Cl}_{50}=47.5 \pm 0.7 \mu \mathrm{M}\right)$, and cervical cancer $\left(\mathrm{HeLa} \mathrm{Cl}_{50}=30 \pm 0.4 \mu \mathrm{M}\right.$ (Pontiki et al., 2014).

Several studies showed that the most promising molecules with the cinnamoyl skeleton are those that have ester and amide functions (Figure 9 and Figure 10), and the addition of conjugated groups to the cinnamoyl ring gradually contributes to the inhibitory activity of neoplastic cells. As an example, there is $p$-farnesylcinamic acid (Figure 10) (61), derived from $p$ coumaric acid (5) (Figure 1), which presented $\mathrm{Cl}_{50}$ of $28 \mu \mathrm{M}$ against the geranyl-geranyl protein transferase (GGTase), related to the development of tumor cells (Rowinsky et al., 1999). It is described in the literature that this enzyme is responsible for protein isoprenylation and, when blocked, inhibits the growth of tumor cells (De et al., 2011).

Figure 10: Derivatives of cinnamic acid with antineoplastic action.

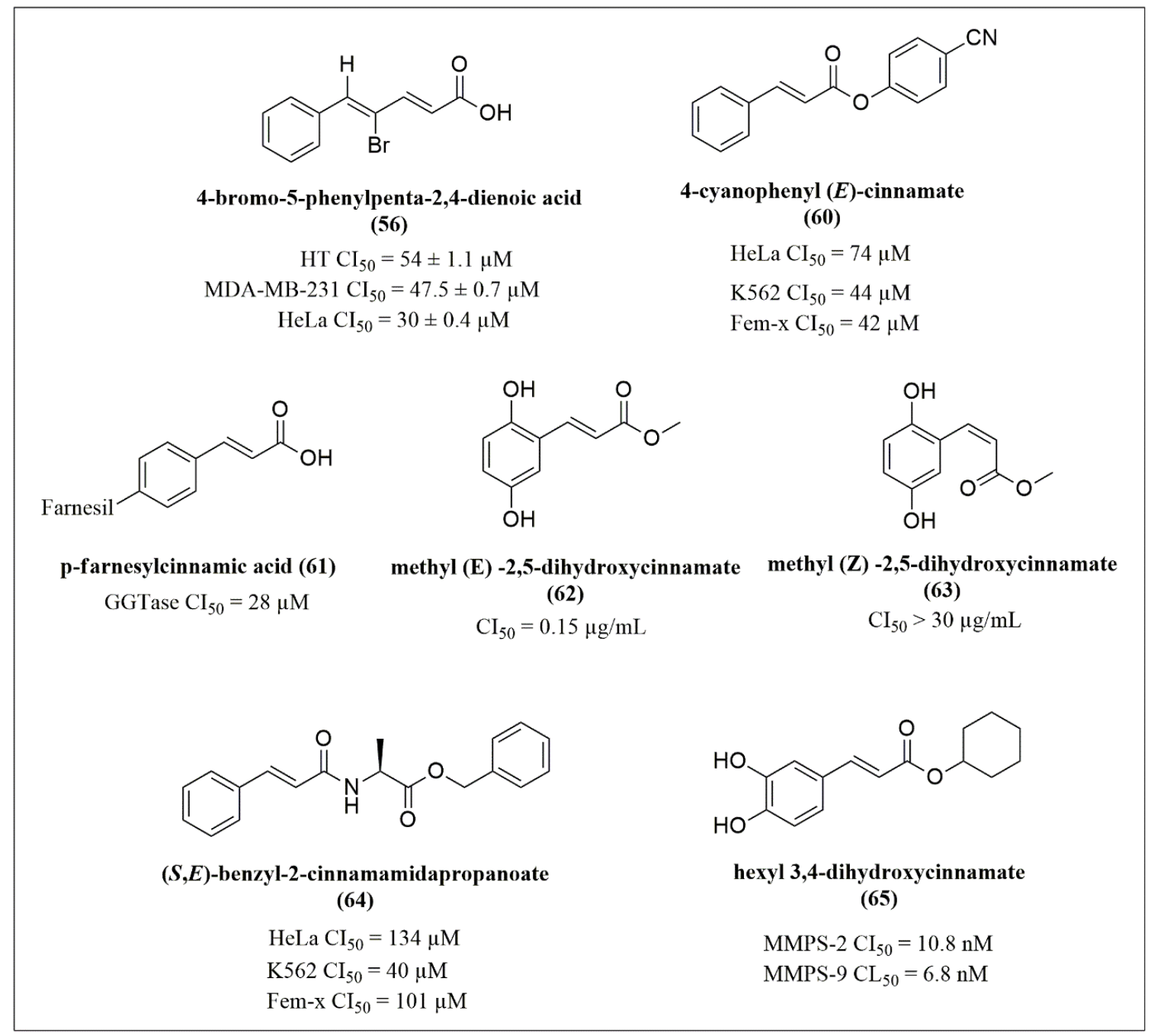

Fonte: Rowinsky et al., (1999); De et al., (2011); Shi et al., (2012); Sova et al., (2013); Pontiki et al., (2014).

Benzoic acid showed no inhibition compared to GGTase, a fact that shows that the $\alpha$, $\beta$-unsaturated bond is important for its inhibition (De et al., 2011). In addition, the geometry configuration contributes to cytotoxic activity, because kinetic esters with trans configuration are more active than their corresponding cis (Figure 10), as seen for methyl $(E)-2,5$-dihydroxycinnamate $\left((62) \mathrm{Cl}_{50}=0.15 \mu \mathrm{g} / \mathrm{mL}\right)$ and its cis isomer ((63) $\left.\mathrm{Cl}_{50}=30 \mu \mathrm{g} / \mathrm{mL}\right)$ (De et al., 2011).

The increase in the anticancer activity of CAD's is also related to the increase in electron withdrawing groups at orto and/or para positions in the aromatic ring of the side chain, which triggers the increase in conjugation and induces the carbonyl esters to become more electrophilic, susceptible to nucleophilic attack. This effect can be observed for the $(E)-4$-cyanophenyl 
cinnamate (Figure 10) (60), which showed antineoplastic activity against the $\mathrm{HeLa}\left(\mathrm{IC}_{50}=74 \mu \mathrm{M}\right), \mathrm{K} 562\left(\mathrm{IC}_{50}=44 \mu \mathrm{M}\right)$, and Fem-x strains $\left(\mathrm{IC}_{50}=42 \mu \mathrm{M}\right)$. When comparing the results obtained for this molecule and those obtained for the cinnamic hybrid ((S,E)-benzyl-2-cinnamamidepropanoate) (Figure 10) (64), which contains the ester and amide function, it is observed that the activity compared to the K562 strain, was more pronounced for the hybrid, with $1_{50}$ of $40 \mu \mathrm{M}$ (Sova et al., 2013).

The molecular docking study showed that strains submitted to these two derivatives had a reduction in their metabolic process, which indicates that they inhibit cell growth through selective induction of apoptosis and interruption of the cell cycle (Jitareanu et al., 2013; Sova et al., 2013).

Cinnamic esters have better anticancer activity compared to amides, to the detriment of their effectiveness against enzymes related to the development of tumor cells, such as MMPS, produced and secreted by neoplastic cells in the extracellular matrix (Pereira et al., 2006; Shi et al., 2012).

The authors shows that caffeic acid (Figure 1) (2) and its derivatives are good inhibitors against MMPS. Caffeic acid (2) has a high inhibitory action on MMPS-2 and MMPS-9, with $1 \mathrm{C}_{50}$ values of 24.3 and $21.3 \mathrm{nM}$, respectively. However, its hexyl 3,4-dihydroxycinnamate derivative (Figure 10) (65) proved to be more effective, with $1 \mathrm{C}_{50}$ values corresponding to 10.8 and $6.8 \mathrm{nM}$ (Shi et al., 2012).

Computational studies shows that the carboxyl function of caffeic acid (Figure 1) (2) and its derivative (hexyl-3,4dihydroxycinnamate) bind to the enzyme through its amino acid residues of alanine, histidine, leucine, valine and glutamate (Figure $10(\mathbf{6 5})$ ), and also shows that the ester carbonyl chelates with the metallic zinc ion present at the active enzyme site (Shi et al., 2012).

\section{Conclusion}

Once analysing several CAD's structures in parallel to their biochemical functions, great influence of cinnamoyl group related to the interaction of these molecules and several molecular targets were observed, promoting this class of compounds as flexible and promising on the study of new bioactive products, where medicinal chemistry, organic synthesis and computational methods are essential tools.

Therefore, cinnamic acid and its derivatives may be good candidates as inhibitors toward many molecular targets associated with neoplastic cells, inflammation, free radical elimination, reactive oxygen species, degradation of bioproducts derived from lipid oxidation, among others, featuring as a starting point on the development of antineoplastics, antibiotics, inhibitors, and others. Hence, elaboration of compounds with remarkable biological activities is totally feasible as well as large scale production for applications in technological processes, food, and pharmaceutical industries.

Thus, the studies with cinnamic acid derivatives presented with a high degree of relevance capable of becoming leading compounds with their improved pharmacodynamic and pharmacokinetic properties. Although the synthetic strategies used so far are effective in forming this class of compounds, it is necessary to implement new synthetic studies since they are not sustainable, thus mitigating environmental impacts and producing in appreciable concentrations compounds with therapeutic actions.

\section{Acknowledgments}

We thank the training agencies Coordination for the Improvement of Higher Education Personnel (Capes), the National Scientific and Technological Council (CNPq) and the Research Support Foundation of the State of Alagoas (Fapeal), for their financial support and the Federal University of Alagoas (UFAL) on the contribution to this research. 


\section{References}

Adisakwattana, S. (2017). Cinnamic Acid and Its Derivatives: Mechanisms for Prevention and Management of Diabetes and Its Complications. Nutrients, 9 (163), 1-27.

Augustine, J. K., Boodappa, C., Venkatachaliah, S., \& Mariappan, A. (2014). TiCl4-mediated olefination of aldehydes with acetic acid and alkyl acetates: a stereoselective approach to (E) $\alpha, \beta$-unsaturated carboxylic acids and esters. Tetrahedron Letters, 55(24), 3503-3506.

Bai, Y., He, X., Bai, Y., Sun, Y., Zhao, Z., Chen, X., Li, B., Xie, J., Li, Y., Jia, P., Meng, X., Zhao, Y.,; Ding, Y., Xiao, C., Wang, S., Yu, J., Liao, S., Zhang, Y., Zhu, Z., Zhang, Q., Zhao, Y., Qin, F., Zhang, Y., Wei, X., Zeng, M., Liang, J., Cuan, Y., Shan, G., Fan, T. P., Wu, B., \& Zheng, X. (2019). Polygala tenuifolia-Acori tatarinowii herbal pair as an inspiration for substituted cinnamic alfa-asaronol esters: Design, synthesis, anticonvulsant activity, and inhibition of lactate dehydrogenase study. European Journal of Medicinal Chemistry, 183, 111650.

Belsito, D., Bickers, D., Bruze, M., Calow, P., Greim, H., Hanifin, J. M., Rogers, A. E., Saurat, J. H., Sipes, I. G., \& Tagami, H. (2007). A toxicologic and dermatologic assessment of related esters and alcohols of cinnamic acid and cinnamyl alcohol when used as fragrance ingredients Food and Chemical Toxicology. 45, S1-S23.

Bisogno, F., Mascoti, L., Sanchez, C., Garibotto, F., Giannini, F., Kurina-Sanz, M., \& Enriz, R. (2007). Structure-antifungal activity relationship of cinnamic acid derivatives. Journal of Agricultural and Food Chemistry, 56(26), 10635 -10640.

Buxton, T., Takahashi, S., Doh, A. M. D., Ansah, J. B., Owusu, E. O., \& Kim, C. S. (2019). Insecticidal activities of cinnamic acid esters isolated from Ocimum gratissimum L. and Vitellaria paradoxa Gaertn leaves against Tribolium castaneum Hebst (Coleoptera: Tenebrionidae). Pest Management Science, $76,257-267$

Chen, D., Zhang, B., Liu, X., Li, X., Yang, X., \& Zhou, L. (2018). Bioactivity and structure activity relationship of cinnamic acid derivatives and its heteroaromatic ring analogues as potential high-efficient acaricides against Psoroptes cuniculi. Bioorganic \& Medicinal Chemistry Letters, 28 (6), $1149-1153$.

Chiriac, C., Tanasa, F., \& Onciu, M. (2005). A novel approach in cinnamic acid synthesis: direct synthesis of cinnamic acids from aromatic aldehydes and aliphatic carboxylic acids in the presence of boron tribromide. Molecules, 10(2), 481-487.

Cui, Y., Hu, Y. H., Yu, F., Zheng, J., Chen, L. S., Chen, Q. X., \& Wang, Q. (2016). Inhibition kinetics and molecular simulation of p-substitutedcinnamic acid derivatives on tyrosinase International Journal of Biological Macromolecules, 11, 1289-1297.

De, P., Baltas, M., \& Bedos-Belval, F. (2011). Cinnamic acid derivatives as anticancer agents-a review. Current Medicinal Chemistry, 18 (11), $1672-1703$.

Doria, O. F. Maturana, R. A., RetamaL, A. B., Quintana, L. M., \& Guzmán, L. (2019). N-alkylimidazolium salts functionalized with p-coumaric and cinnamic acid: a study of their antimicrobial and antibiofilm effects. Molecules, 24(19), 3484.

Fathi, E. Majdi, M., Dastan, D., \& Marouf, A. (2019). The spatio-temporal expression of some genes involved in the biosynthetic pathways of terpenes/phenylpropanoids in yarrow (Achillea millefolium). Plant Physiology and Biochemistry, 142, 43-52.

Georgiev, L., Chochkova, M., Ivanova, G., Najdenski, H., Ninova, M., \& Milkova, T. (2012). Radical scavenging and antimicrobial activities of cinnamoyl amides of biogenic monoamines. Riv. Ital. Sost. Grasse, 89(2), 91-102.

Ghafary, S., Ghobadian, R., Mahdavi, M., Nadri, H., Moradi, A., Akbarzadeh, T., Najafi, Z., Sharifzadeh, M., Edraki, N., Moghadam, F. H., \& Amini, M. (2020). Design, synthesis, and evaluation of novel cinnamic acid-tryptamine hybrid for inhibition of acetylcholinesterase and butyrylcholinesterase. DARU Journal of Pharmaceutical Sciences, 28, 346-9

Ghasemzadeh, A., \& Ghasemzadeh, N. (2011). Flavonoids and phenolic acids: role and biochemical activity in plants and human. Journal of Medicinal Plants Research, 5(31), 6697-6703.

Ghosh, S., Chisti, Y., \& Banerjee, U. C. (2012). Production of shikimic acid. Biotechnology Advances, 30(6), $1425-1431$.

Gunia-krzyżak, A., Słoczyńska, K., Popiół, J., Koczurkiewicz, P., Marona, H., \& Pękala. (2018). Cinnamic acid derivatives in cosmetics - current use and future prospects running head: cinnamic acid derivatives in cosmetics. International Journal of Cosmetic Science, 40 (4), $356-366$.

Guzman, J. D. (2014). Natural cinnamic acids, synthetic derivatives and hybrids with antimicrobial activity. Molecules, 19 (12), $19292-19349$.

Hatsuda, M., Kuroda, T., \& Seki, M. (2003). An Improved Synthesis of (E )-Cinnamic Acid Derivatives via the Claisen-Schmidt Condensation Synthetic Communications, 33(3), 427-434.

He, Y., \& Cai, C. (2011). Polymer-supported macrocyclic schiff base palladium complex as an eficiente catalyst for the Heck reaction. Applied Organometallic Chemistry, 25, 799-803.

Hu, Y., Liu, X., Jia, Y., Guo, Y., Wang, Q., \& Chen, Q. (2013). Inhibitory kinetics of chlorocinnamic acids on mushroom tyrosinase. Journal of Bioscience and Bioengineering, 117 (2), 142-146.

Imai, M., Yokoe, H., Tsubuki, M., \&Takahashi, N. (2019). Growth inhibition of human breast and prostate cancer cells by cinnamic acid derivatives and their mechanism of action. Biological and Pharmaceutical Bulletin, 42(7), 1134-1139.

Jitareanu, A., Balan-porcarasu, M., \& Tataringa, G. (2013). Cinnamic acid derivatives and 4-aminoantipyrine amides - synthesis and evaluation of biological properties. Research Journal of Chemical Sciences, 3 (3), 9-13.

Kooti, W., Servatyari, K., Behzadifar, M., Asadi-Samani, M., Sadeghi, F., Nouri, B., \& Marzouni, H. Z. (2017). Effective medicinal plant in câncer treatment, part 2: review study. Journal of evidence-Based Complementary \& Alternative Medicine, 22(4), 982 - 995. 
Koros`ec, B., Sova, M., Turk, S., Kraševec, N., Novak, M., Lah, L., Stojan, J., Podobnik, B., Berne, S., Zupanec, N., Bunc, M., Gobec, S., \& Kome, R. (2013). Antifungal activity of cinnamic acid derivatives involves inhibition of benzoate 4-hidroxylase (CYP53). Journal of Applied Microbiology, 116, 955-966.

Kozlov M., Konduktorov, K. A., Malikova, A., Kamarova, K. A., Shcherbakova, A. S., Solyev, P. N., \& Kochetkov, S. N. (2019). Structural isomers of cinnamic hydroxamic acids block HCV replication via different mechanisms. European Journal of Medicinal Chemistry, $183,111723$.

Kumar, S. S., Begum, A. S., Hira, K., Niazi, S., Kumar B. R. P., Araya, H., \& Fujimoto, Y. (2019). Structure-based design and synthesis of new 4methylcoumarin-based lignans as pro-inflammatory cytokines (TNF- $\alpha$, IL-6 and IL-1 $\beta$ ) inhibitors. Bioorganic Chemistry, 89, 102991.

Kuppusamy, P., Soundharrajan, L., Kim, D. H., Hwang, I. H., \& Choi, K. C. (2019). 4-hydroxy-3-methoxy cinnamic acid accelerate myoblasts differentiation on C2C12 mouse skeletal muscle cells via AKT and ERK 1/2 activation. Phytomedicine, 60, 152873.

Landberg, R., Sunnerheim, K., \& Dimberg, L. H. (2020). Avenanthramides as lipoxygenase inhibitors. Heliyon, 6(6), e04304.

Lao, Z., \& Toy, P. H. (2016). Catalytic Wittig and aza-Wittig reactions. Beilstein Journal of Organic Chemistry, 12, $2577-2587$.

Mabeta, P., Pavić, K., \& Zorc, B. (2018). Insights into the mechanism of antiproliferative effects of primaquine-cinnamic acid conjugates on MCF-7 cells. Acta Pharmaceutica, 68(3), 337-348.

Martínez-Soriano, P. A., Macías-Pérez, J. R., Velázquez, A. M., Camacho-Enriquez, B. C., Pretelín-Castillo, G., Ruiz-Sánchez, M. B., Abrego-Reyes, V. H., Villa-Treviño, S., \& Angeles, E. (2015). Solvent-free synthesis of carboxylic acids and amide analogs of CAPE (caffeic acid phenethyl ester) under infrared irradiation conditions. Green and Sustainable Chemistry, 5(2), 81-91, 2015.

Medvedeva, M., Barinova, K., Melnikova, A., Semenyuk, P., Kolmogorov, V., Gorelkin, P., Erofeev, A., \& Muronetz, V. (2020). Naturally occurring cinnamic acid derivatives prevent amyloid transformation of alphasynuclein. Biochimie, 170, $128-139$.

Meeprom, A., Chan, C., Sompong, W., \& Adisakwattana, S. (2018). Isoferulic acid attenuates methylglyoxal-induced apoptosis in INS-1 rat pancreatic $\beta$-cell through mitochondrial survival pathways and increasing glyoxalase-1 activity. Biomedicine \& Pharmacotherapy, 101, 777-785.

Narasimhan, B., Belsare, D., Pharande, D., Mourya, V., \& Dhake, A. (2004). Esters, amides and substituted derivatives of cinnamic acid: synthesis, antimicrobial activity and QSAR investigations. European Journal of Medicinal Chemistry, 39 (10), 827-834.

Nishikawa, K., Fukuda, H., Abe, M., Nakanishi, K., Taniguchi, T., Nomura, T., Yamaguchi, C., Hiradate, S., Fujii, Y., Okuda, K., \& Shindo, M. (2013). Substituent effects of cis cinnamic acid analogues as plant growh Inhibitors. Phytochemistry, 96, $132-147$.

Park, Y., Kim, S., Lyou, Y., Lee, J., \& Yang, J. (2005). A new type of uncompetitive inhibition of tyrosinase induced by Cl- binding. Biochimie, 87(11), 931-937.

Passos, G. F. S., Gomes, M. G. M., Aquino, T. M., Araújo - Júnior, J. X., De Souza, S. J. M., Cavalcante, J. P. M., Dos Santos, E. C., Bassi, E. J., \& Silva Júnior, E. F. (2020). Computer aided design, synthesis, and antiviral evaluation of novel acrylamides as potential inhibitors of E3-E2-E1 glycoproteins complex from chikungunya virus. Pharmaceuticals, 13(7), 141.

Pawar, P. M., Jarag, K. J., \& Shankarling, S. G. (2011). Environmentally benign and energy efficient methodology for condensation: an interesting facet to the classical Perkin reaction Green Chemistry, 13(8), 2130-2134.

Peperidou, A. Pontiki, E., Hadjipavlou-Litina, D., Voulgari, E., \& Avgoustakis, K. (2017). Multifunctional cinnamic acid derivatives. Molecules, 22 (8), 1247.

Pereira, A. C., Carmo, E. D., Silveira, V. A. S., Amadei, S. U., \& Rosa, L. E. B. (2006). O papel das MMP-2 e -9 no desenvolvimento do carcinoma epidermóide. Revista Brasileira de Cancerologia, 52(3), 257-262.

Pereira, A. S., Shitsuka, D. M., Parreira, F. J., \& Shitsuka, R. (2018). Metodologia da pesquisa científica. Santa Maria: Núcleo de Tecnologia Educacional da Universidade Federal de Santa Maria.

Pontiki, E., Hadjipavlou-Litina, D., Litinas, K., \& Geromichalos, G. Molecules. (2014). Novel cinnamic acid derivatives as antioxidante and anticâncer agents: design, synthesis and modeling studies, 19 (7), 9655-9674.

Procópio, T. F., Fernandes, K. M., Pontual, E. V., Ximenes, R. M., Oliveira, A. R. C., Souza, C. S., Melo, A. M. M. A., Navarro, D. M. A. F., Paiva, P. M. G., Martins, G. F., \& Napoleão, T. H. (2015). Schinus terebinthifolius leaf extract causes Midgut damage, interfering with survival and development of Aedes aegypti larvae. PLOS ONE, 10(5), 1-19.

Rastogi, N., Domadia, P., Shetty, S., \& Dasgupta, D. (2008). Screening of natural phenolic compounds for potential to inhibit bacterial cell division protein FtsZ. Indian Journal of Experimental Biology, 46(11), 783-787.

Rathee, D., Lather, V., Grewal, A. S., \& Dureja, H. (2018). Targeting matrix metalloproteinases with novel diazepine substituted cinnamic acid derivatives: design, synthesis, in vitro and in silico studies. Chemistry Central Journal, 12(1), 1-15.

Ren, G., Cui, X., Yang, E., Yang, F., \& Wu, Y. (2010). Study on the Heck reaction promoted by carbene adduct of cyclopalladated ferrocenylimine and the related reaction mechanism Tetrahedron, 66(23), 4022-4028.

Rodrigues, M. P., Tomaz, D. C., Souza, L. A., Onofre, T. S., Menezes, W. A., Almeida-Silva, J., Ana Marcia Suarez-Fontes, A. M., Almeida, M. R., Silva, A. M., Bressan, G. C., Vannier-Santos, M. A., Fietto, J. L. R., \& Teixeira, R. R. (2019). Synthesis of cinnamic acid derivatives and leishmanicidal activity against Leishmania braziliensis. European Journal of Medicinal Chemistry, 183, 111688.

Rowinsky, E. K., Windle, J. J., \& Hoff, D. D. V. (1999). Ras Protein Farnesyltransferase: A Strategic Target for Anticancer Therapeutic Development. Biology of Neoplasia, 17(11), 3631-3652. 
Research, Society and Development, v. 10, n. 1, e28010111691, 2021

(CC BY 4.0) | ISSN 2525-3409 | DOI: http://dx.doi.org/10.33448/rsd-v10i1.11691

Saito, M. L., \& Lucchini, F. (1997). Substancias do metabolismo secundário de plantas no controle de pragas agrícolas. LECTA, Bragança Paulista. LECTA, Bragança Paulista, 15(1/2), 211-245.

Sano, S., Takemoto, Y., \& Nagao, Y. (2007). (E)-Selective Horner-Wadsworth-Emmons reaction of aldehydes with bis-(2,2,2-trifluoroethyl) phosphonoacetic acid Archive for Organic Chemistry, 8, 93-101.

Saurabh Pagare, S., Bhatia, M., Tripathi, N., Pagare, S., \& Bansal, Y. K. (2015). Secondary metabolites of plants and their role: overview. Current Trends in Biotechnology and Pharmacy, 9(3), $293-304$.

Sharma, P. (2011). Cinnamic acid derivatives: A new chapter of various pharmacological activities. Journal of Chemical and Pharmaceutical Research, 3 (2), 403-423.

Shi, Z., Li, N., Shi, Q., Tang, H., \& Tang, Y. (2012). Design, synthesis, and preliminary evaluation of substituted cinnamic acid esters as selective matrix metalloproteinase inhibitors. Drug Development Research, 73 (6), 317-324.

Sova, M., Turk, S., Stankovic, J., \& Juranic, J. (2013). Cinnamic acid derivatives induce cell cycle arrest in carcinoma cell lines. Medicinal Chemístry, 9 (5), 633-641.

Su, Y., Wua, Z., \& Tian, S. (2013). Oxidative alkoxycarbonylation of terminal alkenes with carbazates. Chemical Communications, 48 (58), 6528-6530.

Teixeira, C., Ventura, C., Gomes, J. R. B., Gomes, P., \& Martins, F. (2020). Cinnamic derivatives as antitubercular agents: characterization by quantitative structure-activity relationship studies. Molecules, 25 (3), 456.

Tonari, K., Mitsui, K., \& Yonemoto, K. (2002). Structure and antibacterial activity of cinnamic acid related compounds. Journal of Oleo Science, 51(4), 271273.

Untura, L. P., \& Rezende, L. F. (2012). A função cognitiva em pacientes submetidos à quimioterapia: uma revisão integrativa. Revista Brasileira de Cancerologia, 58(2), $257-265$.

Vogt, T. (2010). Phenylpropanoid Biosynthesis. Molecular Plant, 3(1), 2-20.

Wadsworth, W. S., \& Emmons, W. D. (1961). The utility of phosphonate carbanions in olefin synthesis. J. Amer. Chem. Soc, 83(7), $1733-1738$.

Wang, Y., Du, G., Gu, C., Xing, F., Dai, B., \& He, L. (2016). N-heterocyclic carbene-catalysed Peterson olefination reaction. Tetrahedron, $72(4), 472-478$.

Weiner, B. (2009). New Methods towards the synthesis of beta-amino acids. University of Groningen.

Zeng, W. W., \& Lai, L. S. (2019). Multiple-physiological benefits of bird's nest fern (Asplenium australasicum) frond extract for dermatological applications. Natural Product Research, 33 (5), 736-741.

Zhang, J., Hao, W., Zhorov, B., Dong, K., \& Jiang, D. (2019). Discovery of a Novel Series of Tricyclic Oxadiazine 4a-Methyl Esters Based on Indoxacarb as Potential Sodium Channel Blocker/ Modulator Insecticides. Agriculture and Food Chemistry, 67(28), 7793-7809.

Zhang, W. X., Wang, H., Cui, H. R., Guo, W. B., Zhou, F., Cai, D. S., Xu, B., Jia, X. H., Huang, X. M., Yang, Y. Q., Chen, H. S., Qi, J. C., Wang, P. L., \& Lei, H. M. (2019). Design, synthesis and biological evaluation of cinnamic acid derivatives with synergetic neuroprotection and angiogenesis effect. European Journal of Medicinal Chemistry, 183(1), 111695. 